\title{
Systematic ichnology of the Mabou and Cumberland groups (Carboniferous) of western Cape Breton Island, eastern Canada, 1: burrows, pits, trails, and coprolites
}

\author{
Dave G. Keighley* and Ron K. Pickerill \\ Department of Geology, University of New Brunswick, Fredericton, New Brunswick E3B 5A3, Canada
}

\author{
Date Received January 14, 1997 \\ Date Accepted June 16, 1997
}

\begin{abstract}
Strata of the Mabou and Cumberland groups (Namurian-Westphalian A) outcrop extensively in western Cape Breton Island. Trace fossils were encountered at various localities, and include: Circulichnus montanus (nom. correct.), Cochlichnus anguineus, Cochlichnus isp., Conichnus isp., Cruziana problematica, Didymaulichnus cf. lyelli, Diplopodichnus biformis, Gordia marina, Helminthopsis abeli, Helminthopsis hieroglyphica, Palaeophycus striatus, cf. Palaeophycus, Phycodes pedum, Planolites beverleyensis, Planolites terraenovae, cf. Planolites, Rusophycus carbonarius, cf. Rusophycus, Selenichnites isp., Taenidium barretti, cf. Taenidium, Thalassinoides suevicus, Undichnus binus (nom. correct.), Undichnus consulcus (nom. correct.), cf. Undichnus, coprolites, interface trails (types A, B, and $C$ ), plug-shaped burrows, small ovate pits (types $A, B$, and $C$ ), and vertical 'escape' structures. In total (including tracks and trackways not described herein), twenty-two ichnogenera have been identified that comprise a total of eighteen named ichnospecies, eight ichnospecies retained in open nomenclature, and thirteen unnamed ichnospecies. A further ten trace-fossil morphologies (comprising twenty different types) are retained in the vernacular.
\end{abstract}

On trouve de vastes affleurements de strates des groupes de Mabou et de Cumberland (Namurien - Westphalien A) dans l'ouest de l'île du Cap-Breton. On y a relevé des ichnofossiles en divers endroits, notamment : le Circulichnus montanus (nom corrigé), le Cochlichnus anguineus, le Cochlichnus isp., le Conichnus isp., le Cruziana problematica, le Didymaulichnus cf. lyelli, le Diplopodichnus biformis, le Gordia marina, le Helminthopsis abeli, le Helminthopsis hieroglyphica, le Palaeophycus striatus, cf. le Palaeophycus, le Phycodes pedum, le Planolites beverleyensis, le Planolites terraenovae, cf. le Planolites, le Rusophycus carbonarius, cf. le Rusophycus, le Selenichnites isp., le Taenidium barretti, cf. le Taenidium, le Thalassinoides suevicus, l'Undichnus binus (nom corrigé), l'Undichnus consulcus (nom corrigé), cf. l'Undichnus, des coprolites, des pistes de reptation de jonction (types A, B et C), des trous de forme cylindrique, de petites fossettes ovées (types A, B et C) et des structures de " fuite" verticales. On a relevé au total (et ce, y compris des traces et des tracés non décrits aux présentes) 22 ichnogenres comprenant 18 ichnoespèces nommées, huit ichnoespèces retenues dans une nomenclature ouverte et 13 ichnoespèces sans nom. On retient en plus les noms vulgaires de dix autres formes d'ichnofossiles (qui comprennent 20 types différents).

[Traduit par la rédaction]

\section{INTRODUCTION}

Strata of the Mabou and Cumberland groups (NamurianWestphalian A) outcrop extensively in western Cape Breton Island (Fig. 1) and have been confidently inferred, by numerous authors (e.g., Belt, 1965; Gibling, 1995; Keighley and Pickerill, 1996a), to be the products of fluvial, floodplain, and lacustrine sedimentation in half grabens maintained by a transtensional tectonic regime. Though the presence of trace fossils in these strata has been noted by other authors (Carroll et al., 1972; Gersib and McCabe, 1981; Pollard, 1988), no systematic description of these ethological sedimentary structures has ever been undertaken. To correct this oversight, and following the recommendations of Shaw (1971), this contribution is the first of two that pro-

*Present Address: Department of Earth Sciences, University of Liverpool, Brownlow Street, Liverpool L69 3BX, U.K. vides systematic descriptions of the specimens we have recovered from the Hastings, Pomquet, and Emery Brook formations of the Mabou Group, and the Port Hood Formation of the Cumberland Group. The second contribution will provide systematic descriptions of tracks and trackways from the above-mentioned formations (further material, that has yet to be described in detail, has been collected by Baird and is currently housed in the Yale/Princeton collections - D. Baird, personal communication, 1994). Future work will assess the palaeoenvironmental distribution of our specimens.

\section{NOMENCLATURAL PROCEDURES AND TERMINOLOGY}

Recent articles by Dzik (1996) and Goldring and Pollard (1996) have resurrected, once again, argument over nomenclatural procedures. As stated in Keighley and Pickerill (1996b) and Pickerill and Keighley (1997), an ichnotaxon (ichnospecies or ichnogenus) is merely a conventional ci- 


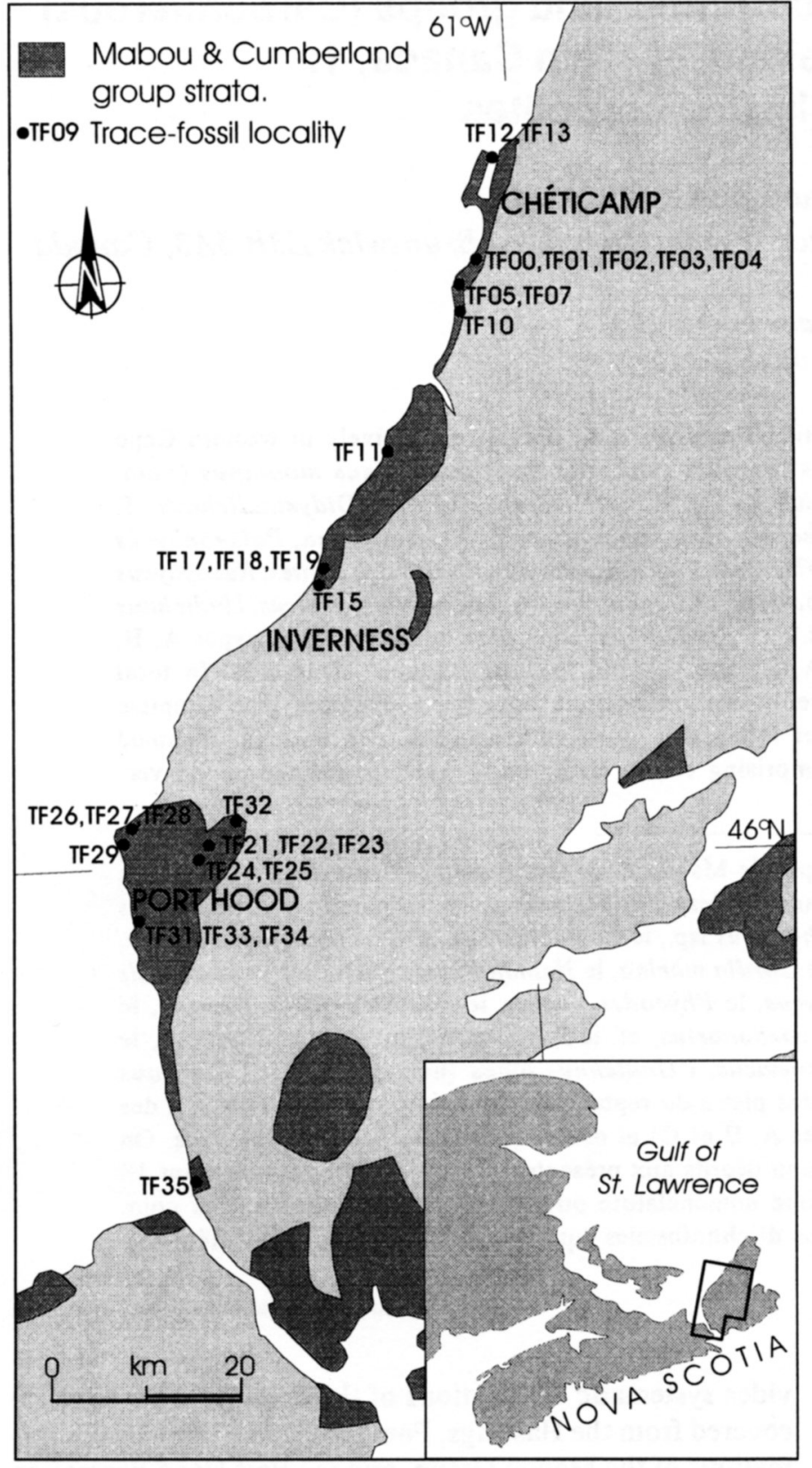

Fig. 1. Location map of trace-fossil localities within the Mabou and Cumberland groups in western Cape Breton Island.

pher that obviates the need for continuous use of a cumbersome descriptive phrase; the descriptive phrase need then only be given in the diagnosis of the ichnotaxon. An ichnospecies should be named (and hence diagnosed) from distinguishing morphological features (cf. Pickerill, 1994; Bromley, 1996), permitting ichnologists to follow the International Code of Zoological Nomenclature (I.C.Z.N. - a binding code governing the use of trace-fossil names) and to adopt the 'Principle of Name-Bearing Types' that allows "...the objective identification of names and for establishing synonymy..." (I.C.Z.N., 1985, p. xvi).

Morphological terminology is not covered by the I.C.Z.N. and, unfortunately, such terminology frequently has different definitions attached to it, potentially causing nomen- clatural confusion. For clarity, therefore, it should be noted that our use of 'burrow', 'wall', 'lining', 'meniscus', and 'branching' follows Keighley and Pickerill $(1994,1995)$. A 'mould' is a 'negative' of the original structure and a 'cast' is a reproduction of the original structure; 'preserving stratum' or 'host stratum' describes the stratum on or in which the trace fossil is preserved. Following Hallam's (1975) interpretation of Seilacher's $(1953,1964)$ terminology, semireliefs are marks at interfaces (whether air/water-sediment, or sedimentsediment) and full reliefs are discrete bodies occurring within strata (not necessarily one stratum) or at interfaces. Essentially, semirelief structures are two-dimensional (tracks and trails), and full relief structures are three-dimensional (burrows, coprolites, rhizoliths). Martinsson's (1970) scheme is subtly different: epichnial traces are located on the top surface of a bed that preserves these traces (in full relief or semirelief) and hypichnial traces are structures located on the bottom surface of the preserved bed (likewise in full relief or semirelief). Consequently, herein the usage of the terms epirelief and hyporelief is different and more specific than the terms epichnial and hypichnial. Martinsson's (1970) other two categories described preservation in the sense of internal and external to the 'main casting medium' (and naturally such traces were all full relief). However, in an interbedded sequence, until either a sandstone or, admittedly more likely, a mudstone is weathered or eroded, both a sandstone and a mudstone that may host a burrow are equally effective 'casting' media. Accordingly, a subjective, a priori, decision would have to be made as to which stratum is going to be preserved, and this is inconsistent with the previously mentioned objective terms. To rectify this problem, the definitions of these latter two terms are modified herein to make them purely descriptive, preservational terms. Endichnial traces are preserved (with full relief) within the preserving strata. Exichnia are located (with full relief) external to the main preserving strata, that is, exichnia must be completely weathered out of the stratum in which they were produced.

With respect to nomenclatural procedures, the I.C.Z.N. (1985) also refrains from dictating what (morphological) criteria, or ichnotaxobases (sensu Bromley, 1996), should be adopted in differentiating ichnotaxa. Accordingly, there are no official guidelines as to what physically constitutes a useful and meaningful ichnogenus or ichnospecies. General consensus follows Fürsich (1974), who directed that ichnogenera be formulated on morphological features resulting from what is interpreted to be behaviour at a high level of significance (significant features), and ichnospecies from features considered to result from behaviour with less importance (accessory features). However, historical precedence (the 'Principle of Priority' - I.C.Z.N., 1985, Article 23) frequently has to override Fürsich's directive.

Additionally, until recently, no guidelines have been presented that deal with trace fossils that have been taphonomically altered, or those that grade into different morphologies. In the broadest sense, taphonomy comprises the study of the processes acting upon an organism between and including death, final burial, and eventual recovery. For trace fossils, the taphonomic effect begins as soon as the trace has been 
produced, with the readjustment of the sediment (which itself is a function of sediment grain size and consistency note that we would argue that grain size of the preserving stratum and its consistency or firmness are not taphonomic factors in themselves, since they influence the actual production of the trace). Taphonomy may also include partial erosion or soft-sediment deformation, compaction and diagenesis, and finally, the degree of weathering and erosion that the specimen is exposed to in outcrop. Therefore, due to general morphological similarities, different ichnogenera and ichnospecies may become increasingly difficult to distinguish as the taphonomic overprint increases. To this end, MacNaughton and Pickerill (1995) introduced the concept of taphoseries. Taphoseries are unidirectional: morphological detail is progressively lost (MacNaughton and Pickerill, 1995, p. 168). Depending upon which taphonomic overprints have been active, different taphoseries may result from identical original structures. Since ichnotaxa are defined on the basis of their morphology, taphonomy will play an important role in determining the name given to a specimen. Only if all taphonomic criteria were favourable (i.e., inactive) would the true nature of the original trace be preserved. This is frequently not the case. If any of the taphonomic criteria are objectively assessed to have been unfavourable, then the true nature of the original trace can only be inferred. Therefore, if nomenclatural assignment is to remain consistently objective, assignment must be to the morphology as it is preserved (contra MacNaughton and Pickerill, 1995). Accompanying remarks may then comment on the structure's possible occurrence as part of a taphoseries.

Along these same lines, problems also exist as to the distinction of ichnotaxa where one morphology is gradational into another morphology, whether the gradation be due to taphonomic variation, or even the result of a change in the behaviour of the organism. Pickerill (1994) has termed such structures 'compound specimens'. Any one of three procedures outlined by Keighley and Pickerill (1996c) can be, and are here, adopted for naming such compound material.

Goldring et al. (1997, p. 265) have most recently suggested that the nomenclatural citation include "...both the taxonomic and preservational aspects..." of the trace fossil and suggested that the morphology of the trace fossil be given under the "Toponomic expression" or "Taphonomic expression" of the trace fossil deemed to be the senior synonym. We agree that this is preferable to the lumping of material into the senior synonym, but would argue that it is the morphology preserved that, in the citation, should take preference over the senior synonym that has a different toponomic and taphonomic preservation, since it could never be certain that the affiliation to the senior synonym was correct: the suspected senior synonym should be listed (in open nomenclature, because of the uncertainty) beneath the morphological nomenclature as, for example, a toponomic associate or a taphoseries precursor.

\section{SYSTEMATIC ICHNOLOGY}

Burrows, pits, trails, and coprolites were encountered at various localities, designated TF00 to TF36, in western Cape Breton Island. In total sixteen ichnogenera were identified that comprise a total of sixteen named ichnospecies, six ichnospecies retained in open nomenclature, and three unnamed ichnospecies. A further five trace-fossil morphologies (comprising nine different types) were retained in the vernacular. Every separate toponomic occurrence of trace fossils has been given an 'assemblage' number with each different trace-fossil assemblage at a particular locality distinguished with a separate letter. A complete assemblage number, for example, would be 'TF09a' (note that no assemblages from localities TF06, TF09, and TF 14 exist, as the material is now considered nonbiogenic). Collected specimens are all presently housed in the Geology Department at the University of New Brunswick(U.N.B. S-255), except where specified to be in the Palaeontological Collections at the New Brunswick Museum (N.B.M.G.) at Saint John.

Following, Häntzschel (1975) and Fillion and Pickerill (1990), the specimens are presented with formally named ichnotaxa first, in alphabetical order. With the current material, differing degrees of confidence in the assigned ichnotaxa are designated by 'cf.'. If 'cf.' is located between the ichnogenus and ichnospecies name, the ichnogenus name is considered definite, although the ichnospecies assignment is less assured (comparable to the ichnospecies definition). If 'cf.' is located before the ichnogenus (or before the ichnogenusichnospecies binomen), the ichnogenus assignment is uncertain.

\section{Ichnogenus Circulichnus Vialov, 1971 (nom. correct.)}

Diagnosis: A completed circular to oval interface trail or burrow (after Vialov, 1971).

Type ichnospecies: Circulichnis montanus Vialov, by original monotypy.

Nomenclatural discussion: Vialov's (1971) original work must be deemed to have an 'incorrect original spelling' for the ichnogenus (I.C.Z.N., Articles 11g, 26, 30a, 32c.i), which should have been spelled Circulichnus. However, even following emendation, the type ichnospecies remains fixed as Circulichnis montanus (I.C.Z.N., Article 67d), although when used to describe new specimens, the corrected spelling should be adopted, that is, Circulichnus montanus.

Vialov's (1971) original diagnosis was in Russian and translates to 'an annular track [trace?] of almost round (or oval) shape, formed by one cylinder'. The comment that his structure was a cylinder suggests that he considered the specimen a burrow. However, later comments that the producing organism subsequently either swam away from the bottom or dug into the sediment, at least indicate that Vialov consid- 
ered the burrow, or trail, to be interfacial. We have been unable to determine whether Vialov's (1971) specimen was preserved in convex hyporelief or not (and hence potentially a trail); however, being an interface trace fossil, we concur with Fillion and Pickerill's (1990) inclusion of both burrows and trails within the diagnosis, since: (a) other recordings of specimens in convex hyporelief or concave epirelief have not all been categorically proven to be burrows, (b) other unilobate interface trace fossils have been regarded as either trails or burrows, and (c) present-day trails from abyssal marine surveys (e.g., Kitchell and Clark, 1979, pl. 4.2) resemble, in size and shape, concave epirelief structures assigned to Circulichnus (e.g., Pickerill et al., 1988, fig. 2a). (See Cochlichnus for further commentary on whether or not there should be nomenclatural distinction between interface trails and burrows.)

Fillion and Pickerill (1990) considered the ichnogenus to be unbranched, although logically, unless the producing organism inhabited its circular burrow/trail perpetually, it must have used an exit (and, or, entry) branch, as suggested by Vialov (1971). This would be particularly so if the structure were a burrow, but not necessarily if it were a trail, since the producing organism may have swum away. One such branch was noted by Pickerill and Keppie (1981). This factor thus leaves the possibility of confusion, and synonymy, with Gordia Emmons. However, with Gordia a complete circle is not achieved, and even the most regular loopings of this ichnogenus form an ' $\alpha$ '-shape. Indeed, Fillion and Pickerill (1990) considered that the type specimen of $C$. ngariensis Yang and Song, later placed into synonymy with C. montanus by Yang (1986), is probably a specimen of Gordia marina Emmons. If this is the case, $C$. ngariensis is not a valid ichnospecies, and Circulichnus remains monoichnospecific.

\section{Circulichnus montanus Vialov, 1971 (nom. correct.) Figures 2A, 2B; 10F}

Diagnosis: As for the ichnogenus.

Description: At least 20 specimens, all from TF03c, are of an irregularly delineated ring ( 1 by $2 \mathrm{~mm}$, up to 8 by 11 $\mathrm{mm}$, short and long diameter) and preserved as epichnial grooves on thin, very-fine-grained sandstone. Although some of these specimens may well be surficial trails, others occur on one slab as hypichnial grooves (Fig. 2A, 2B), and thus are almost certainly interface burrows. The grooves appear as irregular V-shaped structures in cross-sectional profile, and the width of the grooves is always less than $1 \mathrm{~mm}$.

Two of the specimens that occur as hypichnia are visibly connected by a straight groove of $6 \mathrm{~mm}$ length (Fig. $2 \mathrm{~A}$ ), and the same phenomenon is observed between two specimens on another slab. Abundant, irregular and, or, incomplete specimens (assigned as cf. C. montanus) enclose a sandstone surface with an irregular, pustulose surface, whereas elsewhere on the slab, the surface is flat and smooth.

Remarks: Previously described specimens are generally larger, or at least have wider trail or burrow diameters than the present specimens (e.g., Crimes et al., 1981, described specimens of 300 to $600 \mathrm{~mm}$ circular diameter and $10 \mathrm{~mm}$ burrow diameter), though those of Pickerill et al. (1988) are of comparable size. In any case, a one-dimensional size difference such as width of burrow is a poor ichnotaxobase, indicating only that the organism(s) responsible was a different size to other recorded instances.

Circulichnus has been noted to be a eurybathic form (Fillion and Pickerill, 1984). The only previous recording from a nonmarine environment, however, is from Carboniferous deep lacustrine setting in Argentina (Buatois and Mángano, 1993).

Vialov (1971) considered the trace to be produced by the circular, locomotive motion of a worm, and not of one feeding from a sedentary burrow - an interpretation shared by Pickerill and Keppie (1981). Alternatively, and particularly in the case of interface trails, the producing organism may have been 'trapping' food within the ring. In the present material, the presence of a pustulose 'film' of sediment within the ring may signify that a mucous layer, for trapping food, was once enclosed by the trail.

\section{Ichnogenus Cochlichnus Hitchcock, 1858}

Diagnosis: Continuously and regularly meandering interface burrows and trails that resemble at least one full sine or clothoid wave. Successive waves may gradually diminish in amplitude (modified from Hitchcock, 1858; Häntzschel, 1975).

\footnotetext{
Fig. 2. $\mathrm{A}=$ Circulichnus montanus, preserved as concave hypichnia, from TF03c (mag. $x$ 3.6) - the complete specimen (left) is connected to the incomplete specimen (i.e., cf. C. montanus) by a $6 \mathrm{~mm}$ long groove. B = cf. Circulichnus montanus, preserved as concave hypichnia, and small ovate pits, type A, preserved as convex hypichnia, from TF03c (mag. $\mathrm{x} 3$ ). $\mathrm{C}=$ Cochlichnus anguineus, Cochlichnus isp., Undichnus consulcus, and Undichnus binus, all preserved as concave epichnia, from TF26b/i (mag. $x$ 0.35) - these varied trails, likely swimming trails, were produced on a slightly hummocky (small-scale) surface of a fine-grained sandstone. $U$. consulcus is arrowed, and the bracketed areas are detailed in Figure 2D and 2F. D = Detail of Figure 2C showing Cochlichnus isp. as intermittent sinusoidal trails (small arrows) and a horse-shoe-shaped trail (large arrow) that likely marked the point where the producer 'doubled-back' on itself (mag. $x$ 0.8). $\mathrm{E}=$ Cochlichnus anguineus from TF26b (mag. $x 0.5$ ) - the actual preservation of this specimen (convexly epichnial or hypichnial) is uncertain. $\mathrm{F}=$ Detail of Figure $2 \mathrm{C}$ showing Cochlichnus anguineus (thick arrow) and Undichnus binus (thin arrow), (mag. $x 1$ ). $G=$ Conichnus isp., preserved as convex hypichnia, from TF26a - these specimens occur as convex hypichnia on the undersurface of the same slab illustrated in Figure $2 \mathrm{C}$ (mag. $\times 0.5$ ). $\mathrm{H}=\mathrm{Cross}$-sectional view of Conichnus isp. from TF26a (mag. $\times 1.15$ ) - the central specimen illustrated in Figure $2 \mathrm{G}$ is here shown in vertical section after slabbing. A siltstone lamination has been dissected by the trace fossil (arrowed).
} 

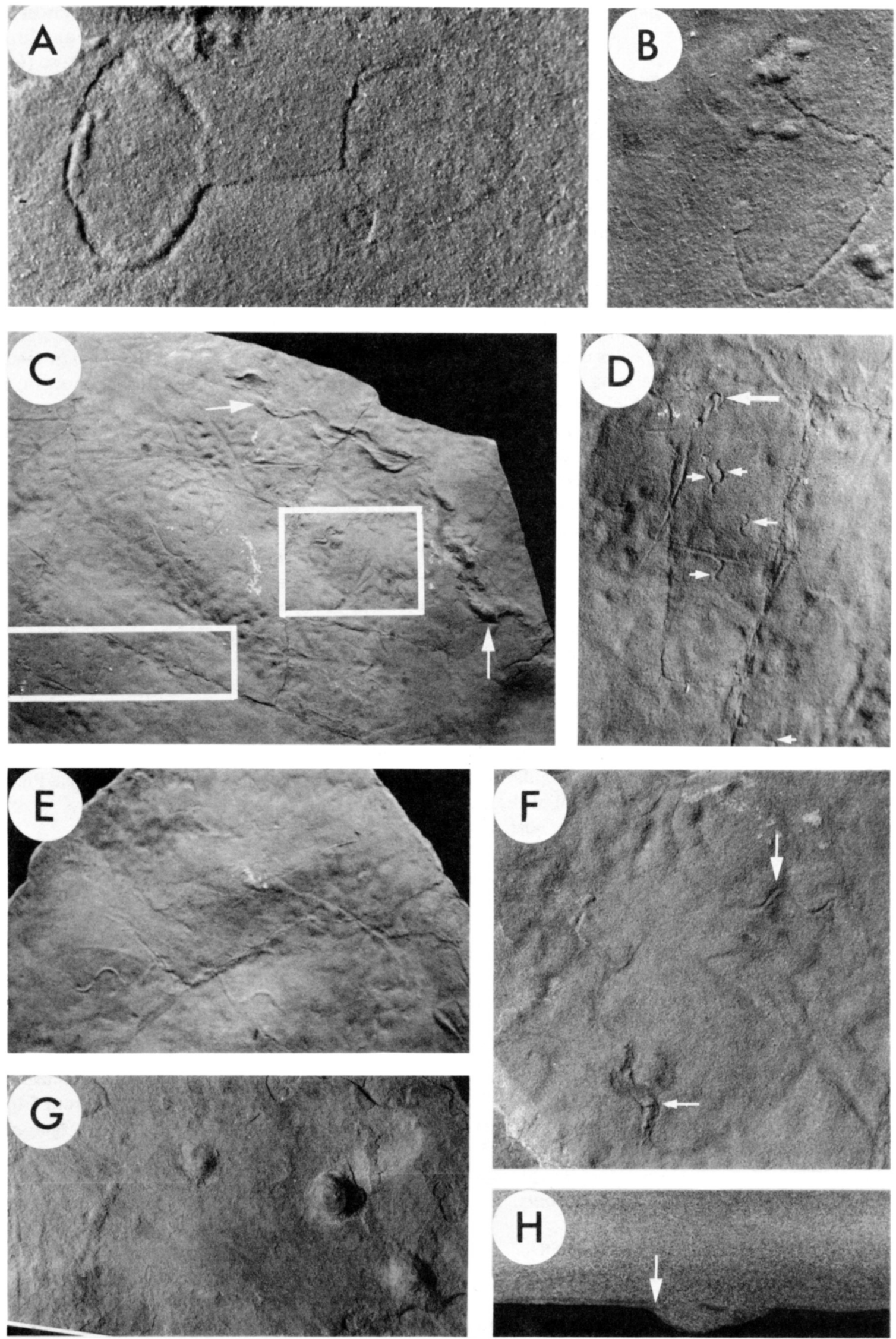
Type ichnospecies: Cochlichnus anguineus Hitchcock, by original monotypy.

Nomenclatural discussion: Though originally monoichnospecific, several additional ichnospecies have been subsequently introduced, namely: Cochlichnus kochi Ludwig, $C$. antarcticus Tasch, $C$. serpens Webby, $C$. lagartensis Muniz, $C$. duomaenensis Yang, $C$. sousensis Muniz, $C$. surpuliformis Yang and $\mathrm{Hu}$, and $C$. annulatus Orlowski. The status of several of these ichnospecies is actually dependent upon whether the original interface structure was a burrow, trail, or a 'burrow/ trail' (in concave epirelief, of course, interface burrows and trails cannot be distinguished - 'burrows/trails' is used to denote where either case might apply). Fillion and Pickerill (1990) concluded that the type ichnospecies could be either a burrow or a trail and thus that there is no difference between it and $C$. kochi or $C$. serpens, which have both been described as being burrows and trails (Michelau, 1956; Webby, 1970), and so both should be potentially considered junior synonyms of $C$. anguineus. $C$. sousensis can be readily included within $C$. anguineus for similar reasons to those suggested by Stanley and Pickerill (1998) for the synonymy of $C$. duomaensis and $C$. surpuliformis within $C$. anguineus. Similarly, though a new ichnogenus, Cymataulus Rindsberg, was erected for sinusoidally meandering, cylindrical burrows (Rindsberg, 1994), other specimens have been described in both modes of preservation, and stability of usage (as a burrow/trail) exists for the ichnogenus. As with Sinusia Krestew, and Sinusites Demanet and Van Straelen, Cymataulus likely is best considered a junior synonym of Cochlichnus.

$C$. annulatus (and possibly C. antarcticus) seems to be a distinct form, in that it exhibits transverse annulations, and the holotype has an infill different from that of the enclosing sandstone. An infill that differs from the host stratum implies an ethology different from the usually postulated, purely locomotive activity, and that the structure was a burrow of some sort. The production of a clothoid curve implies locomotive behaviour by the producer, specifically by undulations of the whole body (Gray, 1953; Wallace, 1968). This is achieved by having one muscle contracting on one side of the body while the corresponding muscle on the other side is stretching. Annulations, on the other hand, imply simultaneous contraction of laterally equivalent musculature. Similarly, the production of a clothoid curve indicates exclusively locomotive behaviour. For the burrow to have a fill different from the enclosing strata could indicate internal processing and backfill. Ethologically, therefore, $C$. annulatus is somewhat of an aberrant form, though morphologically it is still accommodated in Cochlichnus.

\section{Cochlichnus anguineus Hitchcock, 1858 \\ Figure 2C, 2E, 2F}

Diagnosis: Smooth, regularly meandering interface burrows or trails that resemble a full sine or clothoid wave (after Hitchcock, 1858).

Description: One specimen forming part of TF26b (Fig. 2F) is preserved as a concave epichnion on a gently undulating and wave rippled, very-fine-grained sandstone. The specimen, less than $1 \mathrm{~mm}$ wide and with an amplitude of $4 \mathrm{~mm}$, exhibits barely one full sine/clothoid wave (of wavelength $=9 \mathrm{~mm}$ ) and three apices along its $15 \mathrm{~mm}$ length.

A larger specimen on another slab from the same assemblage (Fig. 2E) was collected from talus at the foot of a disused quarry face, and its precise bedding relationship cannot be determined - the sandstone is only gently symmetrically rippled and way-up cannot be determined. It might represent the same bedding surface as shown in Figure $2 \mathrm{~F}$ or the underside of the immediately superseding sandstone bed. Therefore, an interfacial burrow preserved epichnially cannot be conclusively ruled out for this specimen, but there is no evidence of burrow collapse, or that the burrow had been actively backfilled - a convex hypichnion is the preferred interpretation. This specimen forms a smooth, unbranched, interface structure of 0.5 to $1.5 \mathrm{~mm}$ diameter. There are four, regular sine waves with an amplitude between 8 to $10 \mathrm{~mm}$, and a wavelength of 18 to $20 \mathrm{~mm}$ (the larger diameter correlating with larger amplitude and larger wavelength). The overall direction of movement is slightly curved.

Remarks: A vermiform animal is the most typically inferred producer of these traces (e.g., nematodes, as observed by Moussa, 1970, and Metz, 1998; or annelids that typically lack parapodia as suggested by Hakes, 1976), though Metz (1992) observed that short-bodied organisms such as insects can also produce such structures. With such a variety of potential producers it is not surprising that the trace has been found in marine and nonmarine environments, the latter including lacustrine, swamp, floodplain, and fluvial environments (see Keighley, 1996, unpublished Ph.D. thesis, for examples).

\section{Cochlichnus isp. Figure 2D}

Description: The only specimen, preserved as a concave epichnion on the same sandstone bed described above for C. anguineus, comprises four, separate, offset sine waves of barely one full wavelength, together with a crescent-shaped groove that has its cusps pointing toward the adjacent, offset waves. Each component has a $<1 \mathrm{~mm}$ wide groove. The crescent has a diameter of $4 \mathrm{~mm}$ at the cusps. The wavelengths of the individual waves range from 5 to $7 \mathrm{~mm}$, and amplitudes range from 3 to $5 \mathrm{~mm}$, the larger amplitude accompanying the larger wavelengths.

Remarks: The individual waves and crescent are interpreted to be disconnected or intermittent parts of the same interface burrow/trail. The crescent-shaped groove would demarcate a reversal in direction of travel by the producer. Most of the sine waves would then have been formed when the producer was moving in one direction, the other waves when it was moving in the opposite direction. Under this interpretation the likely producer was a vermiform organism that was only intermittently in contact with the preserving medium (either swimming just above the substrate, or burrowing through sediment just above the preserving medium). The alterna- 
tive interpretation, whereby the offset sine waves were produced by the left and right limbs of a vertebrate swimmer moving in one direction, cannot adequately account for the crescent-shaped groove.

The intermittent nature of the sine curves is a previously unreported phenomenon that may ultimately warrant a new ichnospecies name (though individual waves would be assignable to $C$. anguineus). However, it is best to refrain from such a nomenclatural act until additional specimens are found.

\section{Ichnogenus Conichnus Myannil, 1966}

Diagnosis: Conical, amphora-like, or acuminated subcylindrical structures oriented perpendicular to bedding; base may be rounded. Filling may be structured, such as with chevron laminae, but not radially symmetrical (after Pemberton et al., 1988).

Type ichnospecies: Conichnus conicus Myannil, by original monotypy.

Nomenclatural discussion: In comparing the specimens from the study area with the diagnoses provided for plug-shaped ichnogenera by Pemberton et al. (1988), only Conichnus and Bergaueria Prantl accommodate internally structureless, simple conical forms that have an unornamented surface. Dolopichnus Alpert and Moore has a central core in the fill, Calycraterion Karaszewski and Margaritichnus Bandel have a more complex form that is not conical in shape, and Conostichus Lesquereux, Astropolichnus Crimes and Anderson, and Mammillichnus Chamberlain are externally ornamented.

Both Bergaueria and Conichnus were noted to be entirely composed of ichnospecies that had distinct, albeit in some cases very thin, linings, although their ichnogeneric diagnoses do not preclude the existence of unlined ichnospecies. Bergaueria and Conichnus were distinguished from each other by their overall geometry. According to Pemberton et al. (1988, pp. 870-871, 878, and tables 1 and 2), Conichnus has a diameter less than its depth, and Bergaueria has a diameter greater than its depth, suggesting that the Port Hood Formation specimens are better included in the former ichnogenus. However, Bergaueria typically has a hemispherical base and cylindrical sides and, though not a reliable ichnotaxobase, commonly occurs in clusters; Conichnus has tapering sides with a rounded, but not necessarily hemispherical base. Typically, it has also been encountered as isolated specimens. Consequently, we favour assignment of our specimens to Conichnus.

\section{Conichnus isp. Figure 2G, 2H}

Description: All four specimens are from TF26a and occur on the flat base of a slab of very-fine-grained sandstone, the top surface of which contains specimens of Cochlichnus and Undichnus. As the slab was collected from talus, there is no direct evidence of the nature of the underlying substrate, though from the typical occurrence of such fine-grained sand- stone at the particular locality, it is very likely that the underlying bed was mudstone.

The specimens are all ovate in hypichnial plan view (Fig. 2G), ranging from 11 by $8 \mathrm{~mm}$, to 20 by $15 \mathrm{~mm}$ (Table 1). In vertical section they are distinctly conical in shape with gently rounded bases, and are slightly less deep than their minimum diameter. The surfaces are smooth, bearing no ornamentation. When slabbed and viewed in vertical section, the fill is massive, but a silty lamination that is present 1 to $2 \mathrm{~mm}$ above (and parallels the base of the sandstone, is dissected by the massive fill (Fig. 2H). Overlying, diffuse laminae are undisturbed.

Remarks: Two ichnospecies were deemed valid by Pemberton et al. (1988): Conichnus conicus Myannil, and C. papillatus (Myannil). The former ichnospecies is without an apical ornament, the latter has an apical protuberance. Though the specimens herein are assigned to Conichnus, they differ from both these ichnospecies in having a diameter to depth (height) ratio of greater than one (Table 1). The maximum diameter to height ratio noted in Pemberton et al. (1988) was 2:3, and the mean ratio was $1: 2$. Additionally, both ichnospecies are supposedly thinly lined or indistinctly lined, though such an ichnotaxobase was not considered exclusive at the ichnogeneric level. Indeed, the lack of a lining in the specimens may be a preservational artifact.

The Port Hood Formation specimens are dissimilar to C. papillatus in that they lack an apical protuberance. They are also smaller than the smallest recorded specimen of $C$. conicus that had a diameter of $35 \mathrm{~mm}$ and a height of 65 mm (Pemberton and Frey, 1983) and others containing an internal structure of internal, nested, funnel-like laminae.

A one-dimensional size parameter should not be considered, by itself, reason for excluding a specimen from a particular ichnotaxon, whereas lack of distinct linings and structured fill are not diagnostically exclusive of $C$. conicus. However, such a difference in two-dimensional shape may ultimately warrant introduction of a new ichnospecies, though with so few specimens having been collected, such a decision has not been made.

The specimens herein described closely resemble material figured as Bengaueria by Eagar et al. (1985), who documented a variety of trace fossils from coal-bearing deltaic sequences. However, their Bergaueria was described from the base of a thin turbidite sandstone. This is most in keeping with a marine environment which their presumed producer inhabited (i.e., sea anemones, Pemberton et al., 1988). Unless sedimentation in an open interdistributary bay is inferred for the origin of the stratum that contains TF26a (brackish water ostracodes have been identified - J.E. Pollard, personal communication, 1994), an anthozoan could not have produced these traces. Alternatively, the lack of any radial ornamentation means that an anthozoan producer is not necessitated, and a freshwater hydrozoan or an epifaunal bivalve may therefore have been the possible producer. Epifaunal bivalves more commonly produce the similar, almond shaped, pit-like ichnofossil Lockeia James (that is bilaterally symmetrical about a median ridge or groove that runs along its long axis). Since a silty lamination is dissected by 
Table 1. Size parameters of Conichnus: this study and Pemberton et al. (1988) compared.

Conichnus isp. (this study)

$\begin{array}{ccccc}\text { Specimen } & \begin{array}{l}\text { Largest } \\ \text { diameter } \\ (\mathrm{mm})\end{array} & \begin{array}{l}\text { Smallest } \\ \text { diameter } \\ (\mathrm{mm})\end{array} & \begin{array}{l}\text { Height } \\ \text { (-or depth, } \\ \mathrm{mm})\end{array} & \begin{array}{l}\text { Average } \\ \text { diameter } \\ \text { to height } \\ \text { ratio }\end{array} \\ 1 & 11 & 8 & 5 & 1.9 \\ 2 & 13 & 12 & 3 & 4.17 \\ 3 & 16 & 15 & 7 & 2.21 \\ 4 & 20 & 15 & 4 & 4.38\end{array}$

Conichnus conicus (Pemberton et al., 1988)

$\begin{array}{lllll}\text { Specimen } & \begin{array}{l}\text { Largest } \\ \text { diameter } \\ (\mathrm{mm})\end{array} & \begin{array}{l}\text { Smallest } \\ \text { diameter } \\ (\mathrm{mm})\end{array} & \begin{array}{l}\text { Height } \\ (-\mathrm{or} \text { depth, } \\ \mathrm{mm})\end{array} & \begin{array}{l}\text { Average } \\ \text { diameter } \\ \text { to height } \\ \text { ratio }\end{array}\end{array}$

\begin{tabular}{lcccc}
$\begin{array}{l}\text { largest } \\
\text { ratio }\end{array}$ & 80 & $\mathrm{n} / \mathrm{a}$ & 120 & 0.67 \\
$\begin{array}{l}\text { smallest } \\
\text { ratio }\end{array}$ & 50 & $\mathrm{n} / \mathrm{a}$ & 190 & 0.26 \\
\hline
\end{tabular}

the massive fill of one of the specimens, it is inferred that the epifaunal producers were still present (or in the process of 'escaping') during the early sedimentation of what is now the preserving stratum.

\section{Ichnogenus Cruziana d'Orbigny, 1842}

Diagnosis: Elongate (length:width ratio $>2: 1$ ), typically ribbonlike, bilobate (rarely unilobate) interface burrows or trails preserved as furrows with median ridges when preserved in concave epirelief (or bilobate trails with median groove when preserved in counterpart convex hyporelief), or paired fur- rows that are in close proximity (less than the width of a furrow apart). Furrows covered by striae in a herringbone or transverse pattern, with or without smooth or longitudinally striate zones peripheral to the inner striae, with or without outer lateral ridges and, or, wisp-like marks if preserved on bedding soles (after Keighley and Pickerill, 1996c).

Type ichnospecies: Cruziana rugosa d'Orbigny, by subsequent designation (Miller, 1889, p. 115).

Nomenclatural discussion: The nomenclatural debate, and reasoning behind the assignment of our material to this ichnogenus, has been addressed by Keighley and Pickerill (1996c).

\section{Cruziana problematica (Schindewolf, 1928) \\ Figure 3A, 3B, 3C}

Diagnosis: Typically narrow, bilobate Cruziana, preserving distinct or indistinct, usually closely spaced and fine striae that are mostly transverse to the path of the trail/burrow or potentially oblique at tighter curves. Longitudinally oriented grooves or ridges external of the bilobate structure are absent (after Keighley and Pickerill, 1996c).

Description: The material is invariably present as convex hypichnia and comprises variably long, bilobate ribbons with a striate ornament. Striae on the lobes are usually present as very thin, densely packed, transverse marks in negative relief. Rarely the ornament is of more complex, transverse to oblique striae that form a feathery pattern. The width of over 60 trails has been measured (Fig. 4): the ribbons from TF17a, TF17b, and TF17d occur on the loaded and toolmarked bases of fine-grained sandstones and are 1.3 to 3.8 $\mathrm{mm}$ wide (Fig. 3A); several additional specimens could not be measured because of their close proximity, or partial overprinting, by other specimens (Fig. 3C). One $7.6 \mathrm{~mm}$ wide specimen from TF25a was recorded on the base of a wave rippled sandstone, and a $23 \mathrm{~mm}$ wide trail from TF03b (Fig. 3B) was recorded on rubbly very-fine-grained sandstone (specimens from TF33a were not measured precisely but were also

Fig. 3. $\mathrm{A}=$ Cruziana problematica and Rusophycus carbonarius, preserved as convex hypichnia, from TF17a (mag. $\mathrm{x} 0.37$ ) - two almost adjoining cruzianids (arrowed), like the many scattered rusophycids, are not preferentially oriented with respect to the presumed palaeocurrent direction that is indicated by the tool marks. Field photograph, specimens not collected. B $=C r u z i a n a$ problematica, preserved as a convex hypichnion, from TF03b (mag. x 1) - this specimen was by far the largest cruzianid encountered in the study area and was from the same site as many Taenidium burrows that were of similar size (possibly an indication of the same producer?). Field photograph, specimen not collected. $C=$ Cruziana problematica and Rusophycus carbonarius, preserved as convex hypichnia, from TF17b (mag. $x$ 1.25) - densely clustered, discrete and compound forms of the two ichnotaxa are present. $D=$ Didymaulichnus cf. lyelli (arrowed) and Helminthopsis hieroglyphica, preserved as convex hypichnia, from TF18c (mag. $x$ 0.15) almost all specimens to the left of the coin are unilobate and assigned to $H$. hieroglyphica. Field photograph, specimens not collected. $\mathrm{E}=$ Didymaulichnus cf. lyelli, preserved as a convex hypichnion, from TF18c (mag. $x 0.55$ ) - the relatively coarse-grained nature of the preserving stratum has precluded any possibility of ascertaining whether this convex hypichnion was striate and alternatively assignable to Cruziana. Field photograph, specimen not collected. $\mathrm{F}=$ Diplopodichnus biformis, preserved as a concave epichnion, from TF03c (mag. x 6.0) - vaguely preserved is a third, median epichnial groove (arrow) and slightly irregular marginal grooves that are likely coalesced punctate imprints. $G=$ Gordia marina, preserved as a concave epichnion, from $T F 15$ a (mag. $x$ 1.35) - the trail seems to preferentially remain close to the crest of the siltstone-draped ripple that trends from top left to bottom right. 
in the 3 to $5 \mathrm{~mm}$ range). Other specimens of uncertain assignment to Cruziana problematica are abundant in TF17a, TF17b, TF17c, and TF17d.

Remarks: $C$. problematica is a facies-crossing ichnotaxon (Keighley and Pickerill, 1996c), but with an increased tendency to be found in a wide variety of nonmarine environments in Carboniferous and younger strata.

\section{Ichnogenus Didymaulichnus Young, 1972}

Diagnosis: Interfacial, straight to gently curving, not systematically meandering, smooth, furrow-like bilobate trails or burrows, bisected longitudinally by a narrow median ridge in epirelief, or as two, typically rounded ridges bisected by a narrow median groove when preserved in hyporelief (after Fillion and Pickerill, 1990).
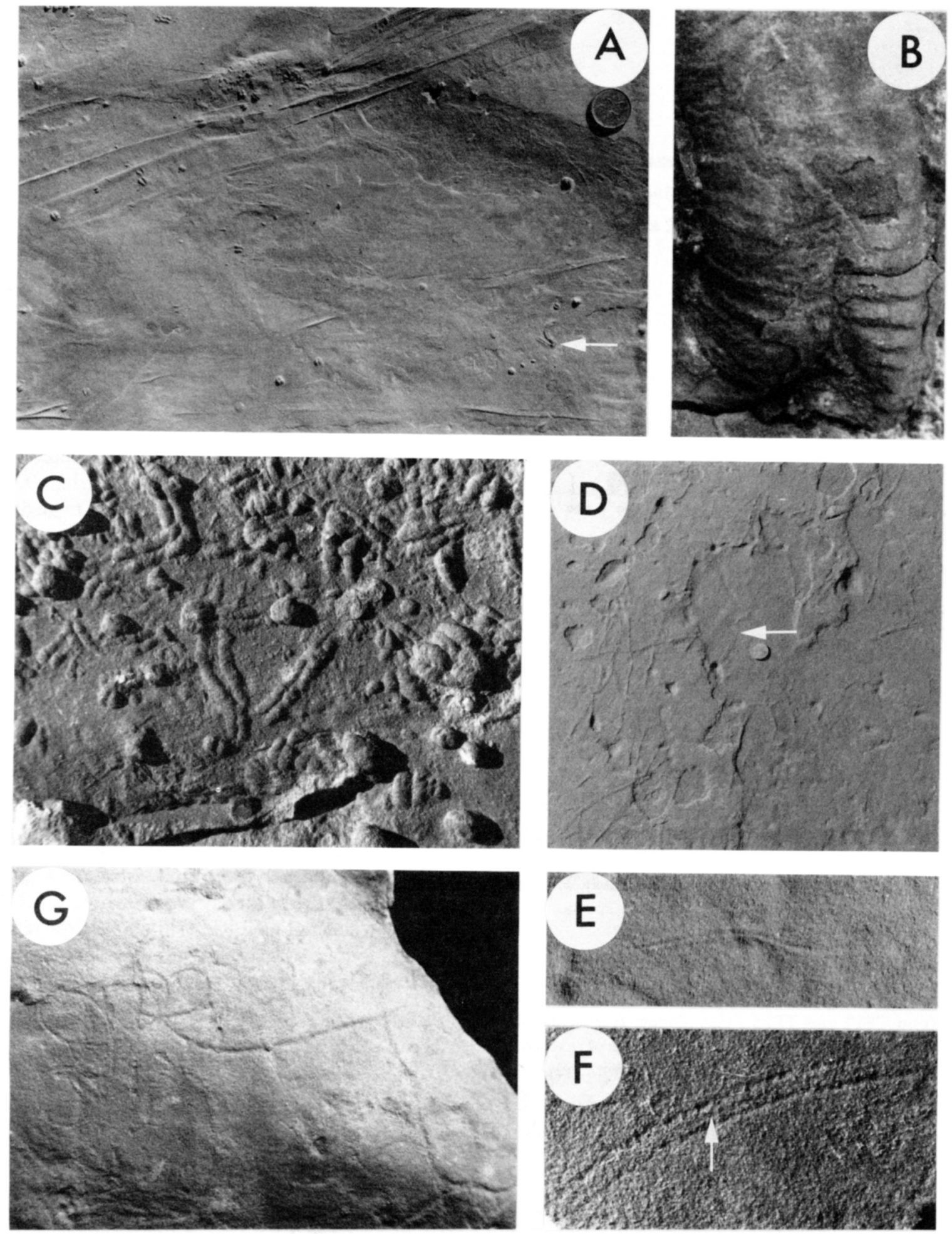

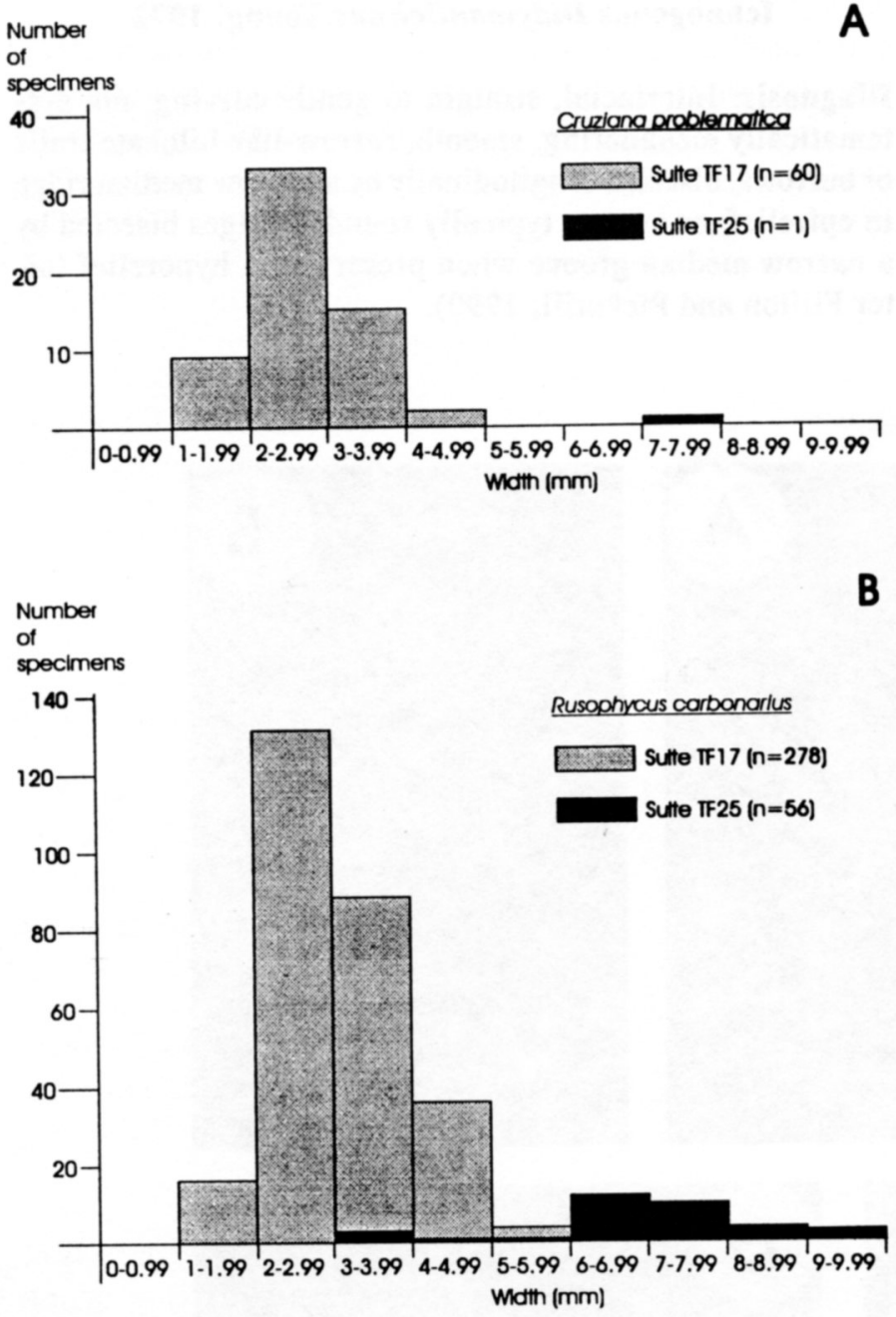

Parallel to current (perpendicular to wave crest)

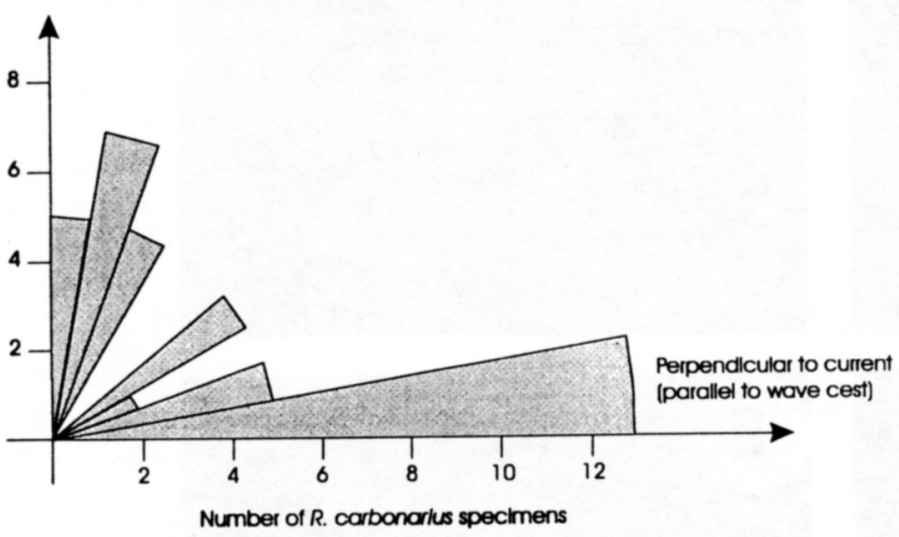

Fig. 4. Size and orientation data for specimens of Cruziana and Rusophycus from TF17 and TF25 assemblages. A = Width distributions of cruzianid material. $\mathrm{B}=$ Width distributions of rusophycid material. $\mathrm{C}=$ Orientation of rusophycid material with respect to palaeocurrent direction (rheotaxis).

Type ichnospecies: Fraena lyelli Rouault, by subsequent designation (Young, 1972).

Discussion: Fillion and Pickerill (1990) and Stanley and Pickerill (1998) have discussed this ichnogenus, recogniz- ing five valid ichnospecies: Didmaulichnus lyelli (Rouault); D. rouaulti (Lebesconte); D. miettensis Young; D. tirasensis Palij; and $D$. alternatus Pickerill, Romano, and Meléndez (though Durand, 1985, had previously considered D. rouaulti a junior synonym of $D$. lyelli). A sixth potential ichnospecies, $D$. nankervisi Bradshaw was questioned by these authors and thought more akin to Pteridichnites Clarke and Swartz, or to Cruziana, because it had thick transverse depressions. We consider it likely that examination of the type material of Pteridichnites would result in its reassignment to Cruziana, the bilobate ichnogenus that, in contrast to the unornamented, smooth surfaced, occasionally bilobate Didymaulichnus, is ornamented by transverse to oblique marks.

Bradshaw (1981) also described $D$. lyelli that included a specimen with rarely occurring oblique scratch marks that can more readily be assigned to Cruziana. Her material, together with that of Dam and Andreassen (1990), from fluvial deposits, and of Aceñolaza and Buatois (1993) from shallow and deep lacustrine deposits, represents the only previously described examples of this ichnogenus from the nonmarine realm, but the ichnogenus is known to be facies crossing and has commonly been described from marine strata (see Fillion and Pickerill, 1990).

\section{Didymaulichnus cf. lyelli (Rouault, 1850) Taphoseries precursor: ?Cruziana problematica Figure 3D, 3E}

Description: Numerous specimens, encountered in the field but not collectable, were preserved hypichnially on large blocks of low angle cross-laminated fine- to medium-grained sandstone (TF18c). The bilobate ribbons were uniform in width $(\sim 3 \mathrm{~mm})$, and generally long and straight with few, slightly sinuous, curves (Fig. 3E). The trails seldom crossed other specimens of $D$. cf. lyelli or specimens of Helminthopis hieroglyphica, and never crossed themselves (Fig. 3D). The lobes were unornamented and lacked marginal ridges or bevels.

Remarks: The material recognized herein is left in open ichnospecific nomenclature because of its poor preservation. However, the specimens have an affinity to the type ichnospecies because, as noted by Fillion and Pickerill (1990), only the type ichnospecies comprises simple, non-undulating, bilobate furrows or ridges. Of course, weathering of the surfaces containing this trace may have obliterated any marginal bevels or ridges, and the relatively coarse nature of the preserving sandstone may not have been suitable for the retention of an ornamentation, which may otherwise have resulted in the specimens being assigned to Cruziana.

\section{Ichnogenus Diplopodichnus Brady, 1947}

Emended diagnosis: Elongate, straight to gently winding, paired furrows (in concave epirelief) or paired ridges (in convex hyporelief). Furrows separated by a distance equal to or greater than the width of the individual furrows and ornamented with indistinct striae or punctate marks (after Keighley and Pickerill, 1996c). 
Type ichnospecies: Diplopodichnus biformis Brady, by original monotypy.

Nomenclatural discussion: The nomenclatural debate, and reasoning behind the assignment of our material to this ichnogenus, has recently been addressed in Keighley and Pickerill (1996c).

\section{Diplopodichnus biformis Brady, 1947 \\ Taphonomic precursor: ? Diplichnites Dawson (sensu lato) \\ Figure 3F}

Emended diagnosis: As for the emended ichnogenus.

Description: One specimen is preserved in concave epirelief on a $5 \mathrm{~mm}$ thick, parallel-laminated, very-fine-grained sandstone (TF03c). It is $<1 \mathrm{~mm}$ wide and $10 \mathrm{~mm}$ long, and toward one end, a vague median groove is preserved (Fig. 3F). The paired furrows run parallel, but each has a slightly irregular outline. Two other possible specimens in the same assemblage (assignable as $\mathrm{cf}$. D. biformis) are compound specimens with interface trails of type B.

Remarks: Synonymous material exhibits a continuous gradation in size (width) up to the 10 to $18 \mathrm{~mm}$ wide specimens of Gevers et al. (1971). The present material, however, is notably smaller in width than even the 3 to $6.5 \mathrm{~mm}$ wide specimens of Johnson et al. (1994).

The irregular outline of the two outer furrows on the specimen in TF03c is interpreted to be the result of an overprinting of punctate appendage marks, the irregular outline directing assignment to Diplopodichnus as opposed to Bilinichnus Fedonkin and Palij (Keighley and Pickerill, 1996c). The localized presence of numerous other, similar trails such as interface trails of type $B$, into which some dubious specimens may merge, is considered to be further evidence that the present specimen was produced by arthropods.

\section{Ichnogenus Gordia Emmons, 1844}

Diagnosis: Smooth, irregularly winding, unbranched interface trails, or cylindrical, massively filled burrows, of uniform diameter with level crossings of the burrow (after Fillion and Pickerill, 1990).

Type ichnospecies: Gordia marina Emmons, by original monotypy.

Nomenclatural discussion: A rather vague description accompanied the original illustration of Gordia (Emmons, 1844, p. 24, pl. 2, fig. 2), and this has led to subsequent confusion and taxonomical inconsistencies. We consider the presence of loopings to best characterize the ichnogenus.

Helminthopsis tenuis Książkiewicz was assigned to Gordia by Häntzschel (1975), although this form completely avoids level crossing of any individual and should be retained in Helminthopsis. Spongiolithus vermicularis Fritsch was placed in Gordia as a separate ichnospecies by Mikuláš (1992). He noted and illustrated that the burrows crossed each other, but since there is no looping within a single burrow, Han and Pickerill's (1995) provisional assignment of the material to Helminthopsis is likely correct. G. maeandria Jiang similarly fails to display level crossings and has more regular meanders, and should not be considered within Gordia. Other ichnospecies previously ascribed to Gordia, namely G. molassica Heer and G. hanyagensis Yang and $\mathrm{Hu}$, can now be ascribed to the type ichnospecies by junior synonymy, following the reasoning of Fillion and Pickerill (1990) and Pickerill and Peel (1991). Three valid ichnospecies of Gordia remain in the current literature, the type ichnospecies $G$. marina, $G$. arcuata Ksiażkiewicz, and G. nodosa Pickerill and Peel.

\section{Gordia marina Emmons, 1844 Figure 3G}

Diagnosis: As for the ichnogenus.

Description: Preservation of the only specimen, from TF15a, is as a concave epirelief on a thin siltstone that drapes a ripple cross-laminated, very-fine-grained sandstone. The trail is thin (uniformly $0.5 \mathrm{~mm}$ wide), smooth and curvilinear, and contains up to five prolate loops with level crossings, preserved on the rounded crest of the ripple. On sloping surfaces, loopings and crossings are rare, but similarly prolate.

Remarks: Although the slab containing this specimen is of limited size, it appears that the tracemaker was actively avoiding the ripple troughs in preference for ripple crests, where the most intense looping has taken place.

Gordia marina is attributed to have been produced by either scavenging or grazing vermiform organisms, or slender, bilaterally symmetrical, arthropod-like animals, and has been recognized as a facies-crossing ichnofossil (Pickerill et al., 1982). In nonmarine environments it has been recognized from lacustrine, playa, levée, sheetflood, and aeolian interdune deposits (see Keighley, 1996, unpublished Ph.D. thesis, for examples).

\section{Ichnogenus Helminthopsis Heer, 1877}

Diagnosis: Unbranched, irregularly winding or meandering, interface burrows or trails that do not touch, cross, or loop themselves. A maximum of one order of nonsinusoidal meandering is present. Burrow fill unstructured (after Han and Pickerill, 1995).

Type ichnospecies: Helminthopsis magna Heer, by subsequent designation (Ulrich, 1904).

Nomenclatural discussion: Han and Pickerill (1995), Wetzel and Bromley (1996), Wetzel et al. (1998), and Pickerill et al. (1998) have recently reviewed this ichnogenus, rationalizing the twenty-two previously described ichnospecies 
into a more manageable three ichnospecies. Wetzel and Bromley's (1996) criteria for diagnosing ichnospecies are either highly arbitrary or poorly defined. Accordingly, following Han and Pickerill (1995) and Pickerill et al. (1997), the three valid ichnospecies are $H$. abeli Ksiązikiewicz and $H$. hieroglyphica Heer, that are distinguished by differences in the surficial winding geometry (see the ichnospecific diagnoses below), and $H$. granulata Ksiażkiewicz that, regardless of surficial geometry, is recognized by a marginal pelletal ornamentation.

It should also be emphasized that Helminthopsis can be distinguished from Palaeophycus and Planolites on the basis that it is exclusively an interface burrow/trail - the other two ichnotaxa being bedding penetrative.

\section{Helminthopsis abeli Książkiewicz, 1977 Figure 5A}

Diagnosis: Loosely winding or meandering interface burrow or trail that does not touch, cross, or loop itself. Meanders irregular and variable in shape, with horseshoe or bellshaped segments, but lacking straight sections. Axes of meanders are not parallel (after Han and Pickerill, 1995).

Description: One distinct specimen from TF19a is a uniformly thin (1-1.5 mm wide), smooth, compressed, quite regularly meandering, interface trail or burrow that lacks straight sections. Other, adjacent, very short vermiform marks may represent additional examples of this ichnospecies. The specimen is preserved as a convex hypichnion on the base of a wave rippled, poorly sorted, micaceous, fine-grained sandstone.

Remarks: Assignment of this specimen to Helminthopsis, as opposed to the distinctly sinusoidal Cochlichnus, is based upon the structure 'curving back' on itself in a partial horseshoeor C-shaped pattern. Such doubling back is not characteristic of a sine or clothoid wave, an essential element for assignment to Cochlichnus. The presence of horseshoe-shaped meanders and lack of straight sections direct the ichnospecific assignment to $H$. abeli.
Helminthopsis abeli has rarely been identified in the nonmarine fossil record. The specimens of Demathieu $e t$ al. (1992) are from nearshore or semi-emergent lacustrine deposits.

\section{Helminthopsis hieroglyphica Heer [in Maillard], 1887 Taphonomic precursor: ? Didymaulichnus (partim.)} Figure 5B, 5C

Diagnosis: Irregularly meandering, unbranched, interface trail or burrow that does not touch, cross, or loop. Straight segments are interspersed with irregularly sinuous sections that are not horseshoe shaped (after Han and Pickerill, 1995).

Description: Abundant material comprising TF00a (Fig. 5C) is present on the sharp crested, linear, wave rippled surface of a thin, very-fine-grained sandstone. The specimens are densely packed, crossing (false branching), full relief, convex epichnia no greater than $1.5 \mathrm{~mm}$ diameter and infilled with whitish, very-fine-grained sandstone, but they are not bedding penetrative. The traces are more common in the ripple troughs and are mostly directed parallel or subparallel to the ripple crests. Abundant specimens, significantly larger than the above but still ubiquitously less than $3 \mathrm{~mm}$ wide, are preserved as convex epichnia on current rippled, finegrained sandstones that have comminuted plant debris in the ripple troughs (TF18a), and horizontally laminated, fineto medium-grained sandstones (TF18b, Fig. 5B). Extensive material is also present on low angle, cross-laminated, fineto medium-grained sandstones (TF12a, and preserved as convex hypichnia in TF18c, Fig. 3D). On the rippled sandstone, burrow turns (of up to $90^{\circ}$ ) are more common and straight sections are relatively rare in comparison to the geometry of the burrows/trails observed on the low angle, cross-laminated sandstones.

Remarks: Helminthopsis is interpreted ethologically to be the result of foraging activity, in this case of a burrowing organism along an immediately subsurface interface. The more common turns in the material from TF $18 \mathrm{a}$ and TF $18 \mathrm{~b}$ may have been the result of a relatively high potential food

Fig. 5. A = Helminthopsis abeli (arrowed), together with other badly preserved trails of indeterminate ichnotaxonomic affinity as convex hypichnia, from TF19a (mag. $x$ 1.25). $\mathrm{B}=$ Helminthopsis hieroglyphica, preserved as convex epichnia, from TF18a (mag. $x$ 0.5). $\mathrm{C}=$ Helminthopsis hieroglyphica, preserved as convex epichnia, from TF00a (mag. $x$ 0.45). D = Palaeophycus striatus and cf. Planolites, preserved endichnially, from TF05a (mag. $\times 2.0$ ) - the distinct, longitudinally oriented striations (arrow) are on the Palaeophycus burrow. The disturbed sediment above it is the vague, parallel burrow provisionally assigned to Planolites (from its appearance when seen in vertical cross-section). $\mathrm{E}=$ Phycodes pedum, preserved as full relief convex hypichnia, from TF29a (mag. $x$ 0.45) - numerous other specimens of possible assignment to Phycodes, and others possibly assignable to Planolites beverleyensis, are present elsewhere on the slab. Field photograph, specimens not collected. $\mathrm{F}=$ Planolites beverleyensis, from TF11b (mag. $\mathrm{xl} .3$ ) - although this specimen exhibits branching at what appear to be fairly regular intervals it is not certain that it is 'true' branching. Additionally, branching is to only one side of the master tunnel, and at highly oblique angles (except for the one bifurcating ramification - bottom of photograph) that would make the specimen of dubious candidacy for alternate inclusion in Chondrites. $\mathrm{G}=$ Planolites beverleyensis, preserved as hypichnial full reliefs, from TF11a (mag. x 0.5 ). $\mathrm{H}=$ Planolites beverleyensis, preserved as convex hypichnia, from TF22a (mag. $x$ 0.45) - specimens appear as small ovate mounds but upon slabbing and observation of vertical sections (Fig. 5I), it was confirmed that the markings were part of vertically undulating burrow systems assignable to $P$. beverleyensis. $\mathrm{I}=$ Cross-sectional view of Planolites beverleyensis illustrated in Figure $5 \mathrm{H}(\mathrm{mag}$. $\mathrm{x} 6$ ) - the burrow structure is revealed (arrow). $\mathrm{J}=$ Planolites terraenovae, preserved as a convex hypichnion, from TF34a (mag. $x$ 1.75) - slabbing of the specimen confirmed that the trace fossil was a burrow and that no lining was present. 

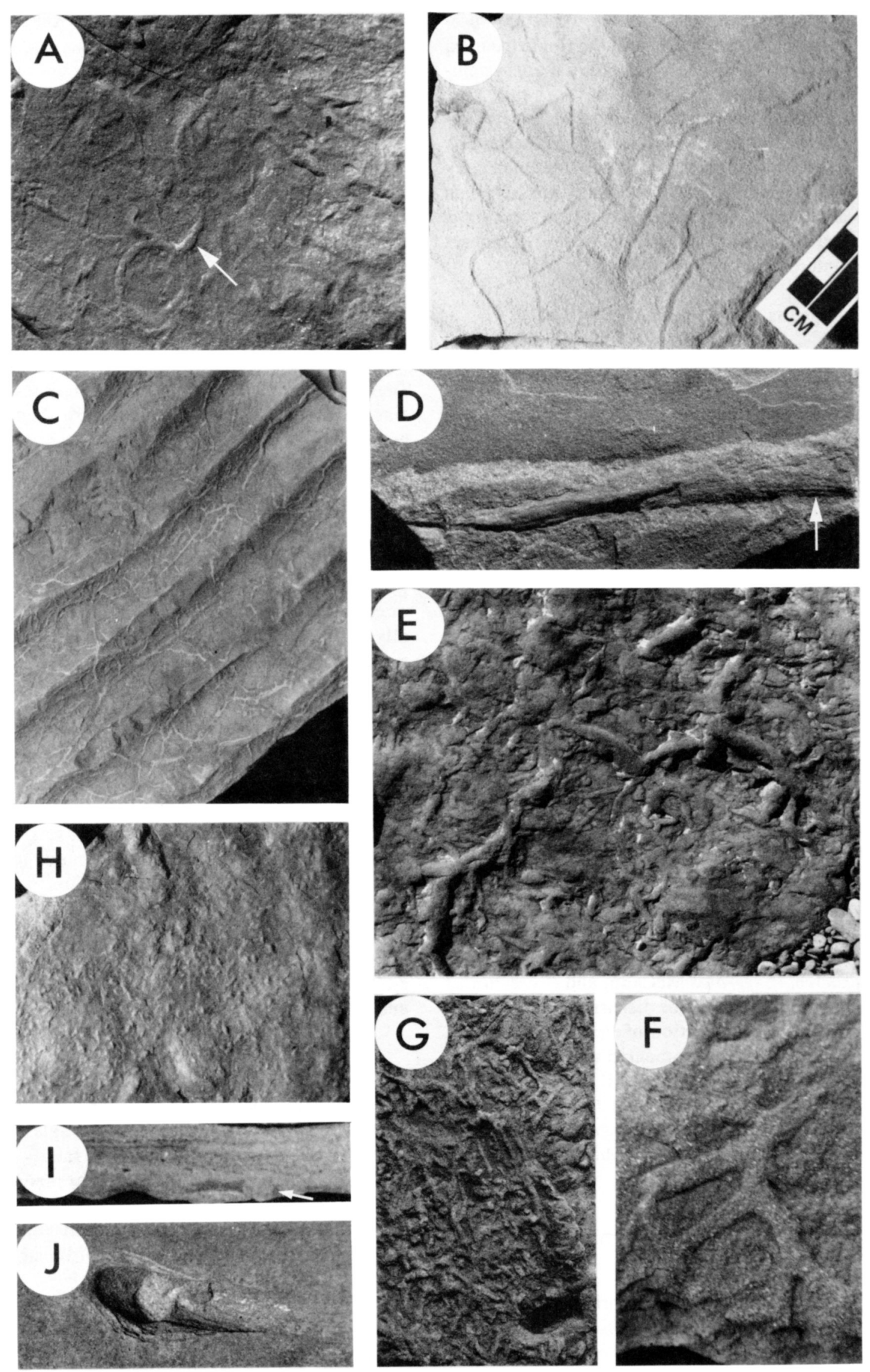
content that was present in the sediment and is now preserved as carbonaceous organic debris in the ripple troughs. A higher food content would likely promote a more systematic coverage of the sediment.

Rather surprisingly for such a commonly identified facies-crossing ichnogenus, records of nonmarine Helminthopsis and $H$. hieroglyphica are uncommon in the literature; only Metz (1992, 1996), Pickerill (1992), and Buatois and Mángano (1993) have noted its occurrence. All of these recordings are from lacustrine deposits, and so this recording appears to be the first interpreted to be from fluvial strata.

\section{Ichnogenus Palaeophycus Hall, 1847}

Diagnosis: Essentially cylindrical, predominantly (sub-) horizontal, straight or slightly curved or slightly undulose, ornamented or smooth, lined burrows. Branched or unbranched, but bifurcation is not systematic, nor does it result in swelling at the ramification points (modified from Fillion and Pickerill, 1990).

Type ichnospecies: Palaeophycus tubularis Hall, by subsequent designation (Miller, 1889, p. 130).

Nomenclatural discussion: Pemberton and Frey (1982) recognized five valid ichnospecies of Palaeophycus out of the 54 that had previously been assigned to the ichnogenus: $P$. tubularis having unornamented, thinly lined walls, $P$. striatus Hall having continuous, parallel striae marginal to a thinly lined burrow, $P$. heberti Saporta having unornamented, thickly lined walls, $P$. sulcatus Miller and Dyer having irregularly anastomosing striae, and $P$. alternatus Pemberton and Frey having alternating striate and annulate sections. It may be argued that $P$. heberti has not been adequately distinguished from $P$. tubularis in that it is unknown what width corresponds to a thick or a thin lining, or whether it is a thickness in relation to overall burrow diameter. Subsequent to Pemberton and Frey's (1982) rationalization of this ichnogenus, at least three new ichnospecies have been introduced, namely $P$. annulatus Badve, $P$. serratus McCann, and $P$. crenulatus Buckman (see Buckman, 1995, for discussion on the validity of these ichnotaxa). Distinction of Palaeophycus from Planolites has recently been commented upon by Keighley and Pickerill (1995) who stated that wall linings and, subordinately burrow fill (and not whether the burrows were originally open or closed), were the diagnostic criteria for distinguishing the two ichnotaxa (contra Miller and Collinson, 1994).

\section{Palaeophycus striatus Hall, 1852 Figure 5D}

Diagnosis: Thinly lined Palaeophycus ornamented by continuous parallel, longitudinal striae (after Pemberton and Frey, 1982).

Description: The only specimen, from TF05a, occurs as a full relief, cylindrical structure toward what is probably the basal surface of its preserving stratum (a silty, cross-lami- nated, very-fine-grained sandstone). Striae are very thin but longitudinal where the lining is preserved. The fill is distinctly finer grained and darker in colour than the host stratum. Adjacent to this $3.5 \mathrm{~mm}$ wide burrow is what is likely a larger second burrow (cf. Planolites), $6 \mathrm{~mm}$ wide and of grain size similar or slightly coarser than its preserving medium.

Remarks: Aceñolaza and Buatois (1991, 1993), GierlowskiKordesch (1991), and Pickerill (1992), have identified the trace fossil from nearshore lacustrine and floodplain palaeosol deposits.

\section{cf. Palaeophycus \\ (not illustrated)}

Description: The one uncollected specimen assigned as TF13a was a weathered, full relief, subcylindrical burrow preserved epichnially on a wave rippled, fine- to medium-grained sandstone. The burrow was of fairly consistent diameter $(\sim 10$ $\mathrm{mm}$ wide) and followed a straight course, virtually normal to, and burrowing through, the crest lines of the wave ripples. The uncollected specimens assigned as TF 30 a were present endichnially and epichnially on cross-stratified, fine- to mediumgrained sandstones. The burrows were typically 5 to $10 \mathrm{~mm}$ diameter, followed relatively straight courses and occasionally crossed (false branching). A lining to the structures was not confirmed in either association.

Remarks: Categorical distinction of Palaeophycus requires that a wall lining be present or very confidently inferred. This is not the case with this material: linings could not be identified with certainty because the specimens were not collectable and no slabbing of the material was possible to produce a fresh surface of the vertical section through any of the burrows. Assignment is provisionally to Palaeophycus since, in both assemblages, burrow linings may have been weathered out. The low density of burrows, straightness, long length, and lack of undulations between beds of the individual burrows, are all uncharacteristic features of Planolites, and direct provisional assignment to Palaeophycus (Keighley and Pickerill, 1995).

\section{Ichnogenus Phycodes Richter, 1850}

Diagnosis: Horizontally bundled burrows, typically preserved in convex hyporelief (?hypichnia). Single main branches, with or without a spreiten structure, ramify either into numerous free branches or in a secund or random fashion. Individual branches cylindrical and finely annulate or smooth; overall pattern of branches being reniform, flabellate, falcate, broom like, bundled, circular, or linear (after Han and Pickerill, 1994).

Type ichnospecies: Phycodes circinatus Richter, by subsequent monotypy.

Nomenclatural discussion: A systematic review of this ichnogenus has recently been completed by Han and Pickerill (1994) and Pickerill et al. (1995), and little additional comment 
of the ichnogenus is required. However, $P$. pedum Seilacher was recently considered by Geyer and Uchman (1995) to be better included within Trichophycus Miller and Dyer as $T$. pedum. Several arguments can be advanced against such an assignment. These authors considered that striate burrow margins and spreite should be secondary, accessory features that distinguish ichnospecies. What constitutes primary and secondary ichnotaxobases is variable, and Osgood (1970), who examined type specimens, previously concluded that for Trichophycus such features were diagnostic at the ichnogeneric level. Additionally, T. venosum Miller, that Osgood (1970) considered most typical of the ichnogenus, has secondary branches initiating on the uppermost surface of the master burrow and, adjacent to such bifurcations, the secondary branches remain bundled to the master burrow for a significant distance. These features are not present in the holotype of $P$. pedum, the specimens from western Cape Breton Island described below, nor in material figured by Geyer and Uchman (1995).

\section{Phycodes pedum Seilacher, 1955 Figure 5E}

Diagnosis: Subhorizontal Phycodes having a straight to falcate master tunnel with shorter secund branches successively bifurcating at regular intervals (after Fillion and Pickerill, 1990).

Description: This material, forming part of TF29a, was observed (but not collected) as convex hypichnia on the lower surface of a thick, massively bedded, fine- to medium-grained sandstone talus. The two best preserved specimens exhibit generally flabellate, straight to slightly curving master tunnels, up to $7 \mathrm{~mm}$ diameter, with single, branches regularly bifurcating horizontally, and mostly secundally from the master tunnel. Burrow fill is similar to the preserving stratum. A plethora of other branching burrows, possibly also assignable herein (as cf. P. pedum), are present within the same slab of sandstone.

Remarks: The material resembles the paratype of $P$. ?antecedens Webby, that Han and Pickerill (1994) consider as a probable junior synonym of $P$. pedum, which do (does) not contain bundled sets of secondary burrows but only periodic, single branchings from the master burrow. Some of the material is also similar to the Y-shaped and 'fleur-de-lys'-shaped branching of the simpler forms of $P$. curvipalmatum Pollard (Pollard, 1981, fig. 7). The present material, however, is considerably larger than either designated types of the aforementioned ichnospecies.

This ichnospecies, to our knowledge, has not previously been recognized from nonmarine strata, although other ichnospecies do seem to be present (e.g., Eagar et al., 1985).

\section{Ichnogenus Planolites Nicholson, 1873}

Diagnosis: Essentially cylindrical, predominantly (sub-) horizontal but bedding penetrative, straight or tortuous, or- namented or smooth, unlined burrows. Unbranched or nonsystematically branched, lacking swelling at any ramification points (modified from Fillion and Pickerill, 1990).

Type ichnospecies: Planolites vulgaris Nicholson and Hinde, 1874 , by subsequent monotypy (= Palaeophycus beverleyensis Billings, by Alpert, 1975; = Planolites beverleyensis (Billings) by Pemberton and Frey, 1982).

Nomenclatural discussion: In their exhaustive review of material assignable to Planolites, Pemberton and Frey (1982) recognized only three distinct forms, namely $P$. beverleyensis, $P$. annularis Walcott, and $P$. montanus Richter (the type ichnospecies, $P$. vulgaris, being, in fact, a junior synonym of $P$. beverleyensis). They distinguished $P$. annulatus on the grounds that it was generally smooth but with transverse annulations; $P$. beverleyensis and $P$. montanus were smooth and lacked these annulations, being distinguished on what was admitted by these authors to be the poor criteria of burrow width and curvature; $P$. montanus was diagnosed as relatively small and $P$. beverleyensis as relatively large. Accompanying remarks stated that '...most specimens of $P$. montanus also are markedly more sinuous and [in a vertical plane,] undulose...' (Pemberton and Frey, 1982, p. 866), with $P$. beverleyensis rarely less than $8 \mathrm{~mm}$ width and $P$. montanus rarely exceeding $5 \mathrm{~mm}$ width. Fillion and Pickerill (1990) were more specific in suggesting a division at $5 \mathrm{~mm}$ width. However, Billings' (1862) type material of $P$. beverleyensis (figured in Pemberton and Frey, 1982, pl. 5) is of variable diameter and several individual specimens are less than 5 $\mathrm{mm}$ wide (though true diameter is not necessarily visible). Neither were any parameters given by Pemberton and Frey (1982) as to how much more sinuous, or how much more undulose, specimens assignable to $P$. montanus should be, nor which of the three parameters was the more important.

Such a one-dimensional size restraint for a burrow is problematical when cross-sections through the burrow are not available; true diameters and apparent widths (chords) cannot be differentiated. Additionally, the one-dimensional size restraint provides no indication of morphological differences, only a variation in scale. Even the 5 to $8 \mathrm{~mm}$ division suggested in Pemberton and Frey's (1982) work has mostly been ignored (Fig. 6). Accordingly, there seems to be no categorical reason to separate $P$. beverleyensis and $P$. montanus, the latter ichnospecies therefore being considered a subjective junior synonym of the former, as previously suggested by Clausen and Vilhjálmsson (1986). Also to be included within $P$. beverleyensis should be $P$. priapus Marintsch and Finks, $P$. zhadaensis Yang and Song, and $P$. maligangensis Wang. As noted by Stanley and Pickerill (1998), P. priapulus was likewise described on the basis of size (greater than $25 \mathrm{~mm}$ diameter in comparison to less than $25 \mathrm{~mm}$ diameter for $P$. beverleyensis) and by an undefined 'degree of straightness'. P. zhadaensis was stated to differ from $P$. montanus by a narrower diameter (though $P$. montanus is supposedly to be used for anything below $5 \mathrm{~mm}$ diameter) and by the density of intersections. Subsequently, $P$. terraenovae Fillion and Pickerill and P. constriannulatus Stanley and 


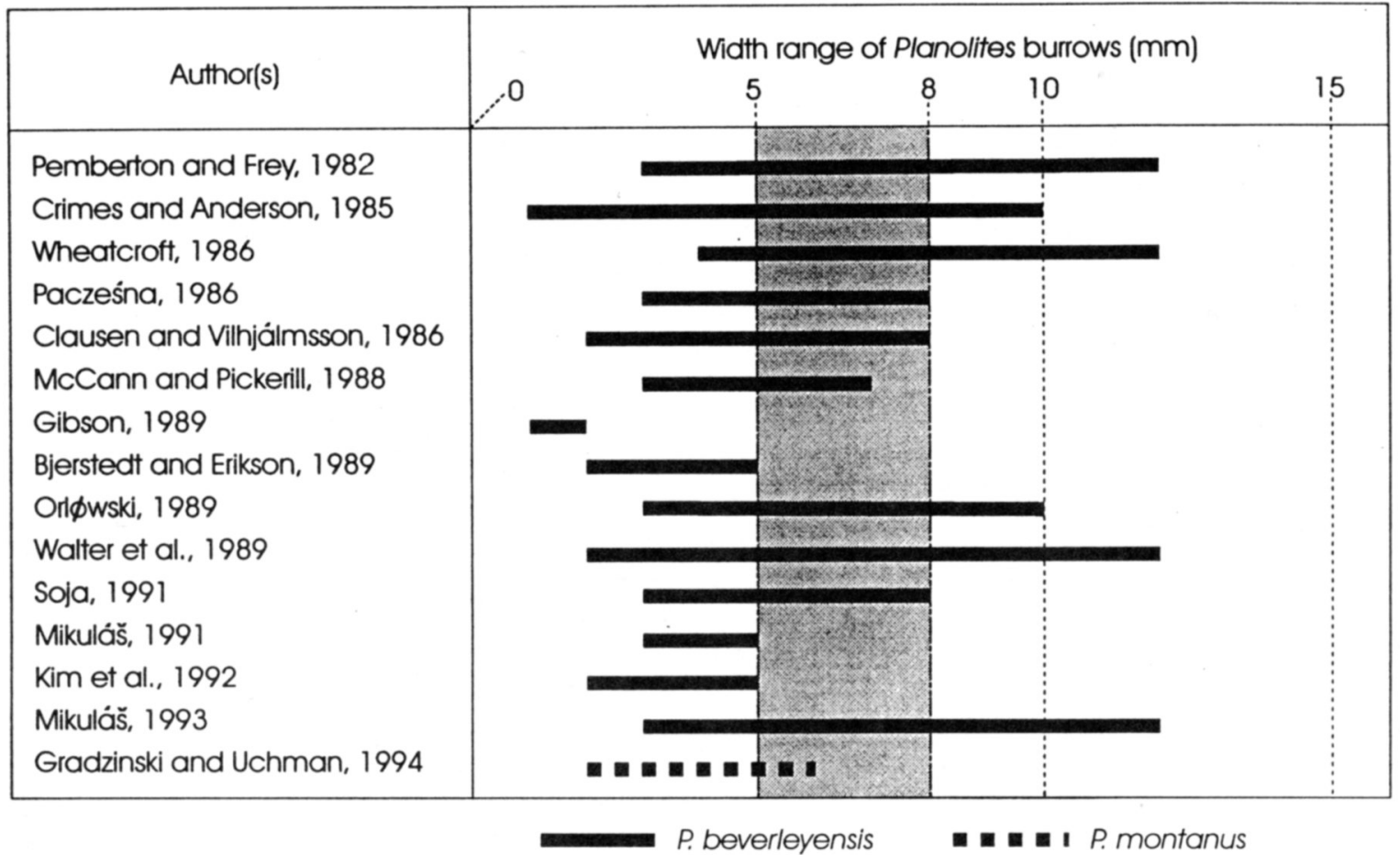

Fig. 6. Widths of selected specimens of Planolites beverleyensis and Planolites montanus from the literature.

Pickerill have been usefully introduced for striate and combined striate and annulate forms respectively.

Planolites beverleyensis (Billings, 1862)

Toponomic associate: Phycodes pedum (partim) Figure 5E, 5F, 5G, 5H, 5I

Diagnosis: Unlined, bedding penetrative, cylindrical burrows lacking surface ornament. Straight, gently curved, tortuous, or undulose in their course (after Pemberton and Frey, 1982).

Description: Specimens are unlined, smooth margined, internally structureless, and, typically, on individual slabs of uniform size and density - although sizes and trace-fossil density differ between the various localities. Abundant material forming TF1la-TF1lc (Fig. 5F, 5G) and TF31a is 1.5 to $3.0 \mathrm{~mm}$ diameter, apparently branching (secondary successive, or false branching is likely), occasionally crossing, and fairly densely packed. The burrows occur as convex hypichnia and endichnia associated with very thin, mediumgrained and fine-grained sandstones that are interbedded with grey mudstones and thicker cross-stratified sandstones. The burrows are mostly bedding penetrative, extending down from the sandstone into the now weathered-away siltstones in the case of the convex hypichnial forms, and vice versa for the concave epichnia. The major specimen on TF1lb (Fig. 5F) is not well preserved, but it does exhibit distinct branching, with secund ramification from the master 4.5 mm wide burrow.

The abundant specimens from the TF22 assemblages (Fig. 5H, 5I) are present in parallel-laminated, very-finegrained sandstones that are moderately bioturbated. The better- defined burrows, $<2 \mathrm{~mm}$ wide, appear in cleavage relief and do not cross or branch (larger cylindrical burrows, $\sim 4 \mathrm{~mm}$ diameter are seen in vertical section). They are generally parallel to bedding, with undulations between different laminae that result in mostly ovate and short, sausage-shaped marks being preserved on the bedding planes (that could, without care, be confused with small Lockeia). Additional material, of likely assignment (as cf. P. beverleyensis), from TF $21 \mathrm{~b}$, comprises similarly small ( $<2 \mathrm{~mm}$ wide by $<6 \mathrm{~mm}$ long), elliptical depressions (on top surfaces) and counterpoint mounds (on bottom surfaces) at thin, silty horizons that are interlaminated with very-fine-grained sandstones. Possible material was also observed, but not collected, as part of TF29a.

Remarks: A very similar style of branching to that seen in TF11b (Fig. 5F) has been illustrated in burrows described as Chondrites Sternberg by Hakes (1976, pl. 4.2). In both cases the branching is secund, and Chondrites should be restricted to material that has bifurcations of the master burrow, rather than side branches emanating from predominantly one side of a master burrow. Secund branching may suggest an affinity to Phycodes, but we are unaware of Phycodes having been recorded where there is further branching of the secondary, free branches. From the preservation of the material, it cannot be determined whether there is primary successive branching (more suggestive ethologically of Chondrites or Phycodes), or whether there is just secondary successive branching. Assignment of these specimens is most safely with Planolites.

A similar problem in the distinction of Planolites and Phycodes is seen in TF29a (Fig. 5E). Here, many of the badly preserved burrows are provisionally assigned to $P$. 
beverleyensis because the nature of the branching is unclear, unlike the distinct branching of the better-preserved burrows in this assemblage that are readily assignable to Phycodes.

In contrast to material from TF11 (Fig. 5G), where undulations are rare, material from the TF22 assemblages (Fig. $5 \mathrm{H})$ occasionally indicates that the burrows undulate between different laminae - this same feature has also been recognized by Stanley and Fagerstrom (1974) who considered the undulations to be sinusoidal in a vertical plane. Our material also highlights the problems of ichnospecific distinction between $P$. beverleyensis and $P$. montanus. Since the TF22 material is more undulate than the TF11 material, the TF22 material is more comparable to Pemberton and Frey's (1982) conception of $P$. montanus (but figured P. montanus in Pemberton and Frey, 1982, is no more undulate than the TF11 specimens). Material from neither assemblage is $>4$ $\mathrm{mm}$ wide, nor particularly sinuous. Consequently, since there are no guidelines as to which criterion should take preference, all material has been assigned to the more senior, prioritized ichnospecies.

Material from TF21 was recovered from similar strata to that described for the TF22 assemblages, and preservation as convex hypichnia superficially resembles $P$. beverleyensis from TF11c and TF22a. No cylindrical burrow structures are visible in (limited) vertical section, and the convex hypichnia, if anything, show the downward relocation of a very thin layer of silt that forms the hypichnial surface. This latter feature suggests that they may have been surface pits (possibly suggesting alternate assignment to cf. Lockeia). The uncertainties as to whether the material represents surface pits or burrows means that direct assignment is not possible: similarities to the $P$. beverleyensis material in TF22a has led to provisional assignment within this ichnospecies.

Planolites beverleyensis (including material previously assigned to $P$. montanus) has been encountered in strata attributable to varied nonmarine depositional environments: lacustrine, crevasse splay, playa, sabkha, fluvial, and aeolian interdune deposits (see Keighley, 1996, unpublished Ph.D. thesis, for examples).

\section{Planolites terraenovae Fillion and Pickerill, 1990 Figure 5J}

Diagnosis: Planolites ornamented by continuous parallel, longitudinal striae (after Fillion and Pickerill, 1990).

Description: The single specimen, from TF34a, is an apparently unlined tubular structure preserved as a convex hypichnion on a thin, ripple cross-laminated, fine-grained sandstone. The tube forms a gentle, asymmetrical U-shaped structure as it protrudes down from the preserving stratum and exhibits, in part, fine striae as continuous grooves that run just oblique of longitudinal. The grooves are slightly oblique and give the impression of being part of a spiralling series of surface striae - though no stria is complete enough to encompass even the entire part of the circumference that is exposed.
Remarks: Planolites terraenovae was introduced by Fillion and Pickerill (1990) for unlined burrows that are continuously striate. Though the present material is not continuously striate, this is considered a taphonomic effect. It is of similar (slightly smaller) length and width to Fillion and Pickerill's (1990) material, and of similar cross-sectional form and hypichnial preservation. Though these authors considered $P$. terraenovae to be actively filled, this criterion is not a valid ichnotaxobase (see Keighley and Pickerill, 1995), and the method of fill cannot be determined in the present material. The primary ichnotaxobase distinguishing Palaeophycus from Planolites is the presence of a wall lining in the former. Assignment is to P. terraenovae and not Palaeophycus striatus because no lining is preserved or indicated. The short up-and-down undulations of the burrows (though not an accepted ichnotaxobase for this ichnotaxon), are also more typical of Planolites, particularly those described in the present study.

\section{cf. Planolites \\ Figure 5D}

Description: TF05a contains a $6 \mathrm{~mm}$ diameter burrow adjacent to another burrow assigned to Palaeophycus striatus (Fig. 5D). Its occurrence was only clearly visible after vertical slabbing. Grain size in the burrow is similar to, or slightly coarser than, the preserving medium.

TF12b has badly preserved specimens (hence the provisional assignment), likely from within the medium-grained, grey sandstone part of an interbedded sandstone-grey mudstone package. Burrows, up to $7 \mathrm{~mm}$ diameter, have a coarser grained fill than the preserving stratum. In neither assemblage do the specimens appear to be walled.

Remarks: Categorical distinction of Planolites requires that a wall lining be absent. This appears to be the case with TF12b, but slabbing of the material into vertical sections did not reveal clear burrow boundaries. Following the recommendations of Keighley and Pickerill (1995), assignment is provisionally to Planolites. Thin linings may have been taphonomically removed, but in this material there are no mitigating circumstances to suggest that they were originally present. Regardless, the high density of burrows, with a fill different to that of the host stratum, are features usually associated with Planolites (though none of these features are useful ichnotaxobases).

The appearance of the burrow in TF05 is only clear in vertically slabbed sections but no wall lining is confidently observed and its actual relationship with the adjacent Palaeophycus striatus is uncertain. The circular structure may not be a separate burrow but, instead, may be related to sediment shifting caused by the production of the Palaeophycus burrow, or some other event. Hence assignment is only provisional.

The size of the TF $12 \mathrm{~b}$ burrows straddles the suggested $5 \mathrm{~mm}$ division between $P$. beverleyensis and $P$. montanus. Though poor preservation negates formal assignment of this material, it illustrates the arbitrary nature of a one-dimen- 
sional size criterion as an ichnotaxobase. Two otherwise identical burrows would be given different names if one was $4.9 \mathrm{~mm}$ wide and the other $5.1 \mathrm{~mm}$ wide.

\section{Ichnogenus Rusophycus Hall, 1852}

Diagnosis: Short (length:width ratio <2:1), interfacial bilobate burrow, or surface mark, resembling a coffee-bean, preserved in convex hyporelief (or, potentially, concave epirelief). Ovate lobes parallel to slightly divergent and may be smooth or exhibit transverse to oblique scratch marks (after Keighley and Pickerill, 1996c).

Type ichnospecies: Rusophycus clavatus Hall, by subsequent designation (Miller, 1889, p. 138 - but see comments by Fillion and Pickerill, 1990, regarding the unsuitability of this ichnospecies and suggestions for the eventual adoption of $R$. biloba (Vanuxem)).

Nomenclatural discussion: The nomenclatural debate, and reasoning behind the assignment of our material to this ichnogenus, is addressed in Keighley and Pickerill (1996c).

\section{Rusophycus carbonarius Dawson, 1868 Figures 3A, 3C; 7A, 7C, 7D}

Emended diagnosis: Interface structures, small, coffee-bean shaped, with transverse to oblique, generally thin striae that do not extend beyond the parallel to slightly gaping lobes (after Keighley and Pickerill, 1996c).

Description: Typically, these coffee-bean shaped, small structures are preserved as convex hypichnia, though specimens from TF25b are preserved as concave epichnia. Two separate, and quite distinct populations of $R$. carbonarius can be distinguished, namely the 56+ present in TF25a and TF25b (Fig. 7A) and the 300+ present elsewhere (TF02b, TF04a, TF17a, TF17b, TF17c, TF17d, TF21a, TF21c, TF22b, uncollected specimens from TF23, and TF33a). They are distinct not only in overall size (Fig. 4), but also in shape. The specimens from TF25a and TF25b are mostly larger and more compact in shape, frequently with the transverse 'width' exceeding the longitudinal 'length'. There is only minimal overlap in size. Typically, three or four, narrow, V-shaped grooves, forming transverse striae, cross each lobe (when preserved as convex hypichnia). Occasionally, lobes are smooth with no striae preserved. However, where these rusophycids occur on the same slabs as the striate forms, this difference is explained as taphonomic, rather than ethological. Further possible specimens (cf. $R$. carbonarius) occur in most of the above assemblages and in TF02c and TF17e.

Remarks: The different size-populations in the material (Fig. 4) are best accounted for by different producers. The qualitatively observed smaller length:width ratio (relative to the length:width ratio of other specimens) in the TF25a and TF25b population probably indicates a producer with a shorter body length. Uniquely, the producers of these latter traces were active on substrates undergoing wave action that might indicate a differing, more specialized, niche for the progenitors of this form. Though a different length:width ratio is present, we do not consider, at this stage, that separation of the material into different ichnospecies is warranted. Larger $R$. carbonarius forming 'deep circular traces' were similarly recorded, along with smaller, less circular specimens, from a wave rippled surface by Pollard (1985, fig. 5). Pollard (1985) noted distinct preferred orientations (rheotaxis) in his material: rippled surfaces had specimens oriented virtually normal to the ripple crests (parallel to the current), and parallel to scour marks on flat surfaces (again parallel to the current). This was considered indicative of producers that were hydrodynamically more streamlined longitudinally. The orientations of specimens on surfaces that contain tool marks (Fig. 3A) were not measured in the present study, but many appear to be nearly perpendicular to the palaeoflow indicated by the tool marks. However, on the wave rippled surfaces of TF25a and TF25b (Fig. 7A), the producers seem to have preferred orientations either parallel or normal to the wave crests rather than oblique orientations (Fig. 4). Perhaps the producers of the studied material were streamlined both when head-on and side-on to a current.

\section{cf. Rusophycus \\ (not figured)}

Description: The preserving stratum of current rippled, veryfine-grained sandstone is weathered and it cannot be ascertained whether the two convex hypichnia present are truly

Fig. 7. $\mathrm{A}=$ Rusophycus carbonarius and plug-like burrows, preserved as concave epichnia, from TF25b (mag. $\mathrm{x} 0.33$ ) - the specimens of $R$. carbonarius (example arrowed) exhibit bidirectional rheotaxis (parallel and perpendicular to the symmetrical wave axes). A plug-like burrow is arrowed (thick arrow). $\mathrm{B}=$ Selenichnites isp. (arrowed) as a compound specimen with the trackway Protichnites cf. kennediea, preserved as convex hypichnia, from TF01a (mag. $\mathrm{x} 1.3$ ). $\mathrm{C}=$ Rusophycus carbonarius, preserved as convex hypichnia, from TF17d (mag. $x$ 1.1) - In places (example arrowed) specimens have been deformed by subsequent softsediment deformation. $\mathrm{D}=$ Rusophycus carbonarius, preserved as convex hypichnia, from TF17b (mag. $\mathrm{x} 1.2$ ). Specimens are prominently convex, with the multiple specimens in the bottom right being $\sim 5 \mathrm{~mm}$ 'above' the bedding surface. $\mathrm{E}=$ Taenidium barretti, preserved as exichnia and endichnia, from TF03a and now housed as NBMG 9074 (mag. $x$ 0.7) - the knobbly exterior resembles the wall ornamentation of burrows assignable to Ophiomorpha, but slabbing of other material (Fig. $7 \mathrm{G}$ ) confirms that there is no wall structure present. $F=$ Taenidium barretti, preserved endichnially, from TF28 (mag. $x 0.18$ ) - field photograph, specimen not collected. $\mathrm{G}=$ Taenidium barretti, from TF03a (mag. $\times 1.4$ ) - the vertical sectioning illustrates the lack of a wall structure (the black margin to the burrow is glue) and the presence of convex-down menisci indicate that the burrower moved upwards from right to left. $\mathrm{H}=\mathrm{cf}$. Undichnus isp., preserved as a convex hypichnion, from TF07a (mag. $x$ 0.55) - specimen is preserved on the base of a wave rippled sandstone (ripple-crests run from left to right). Field photograph, specimen not collected. 

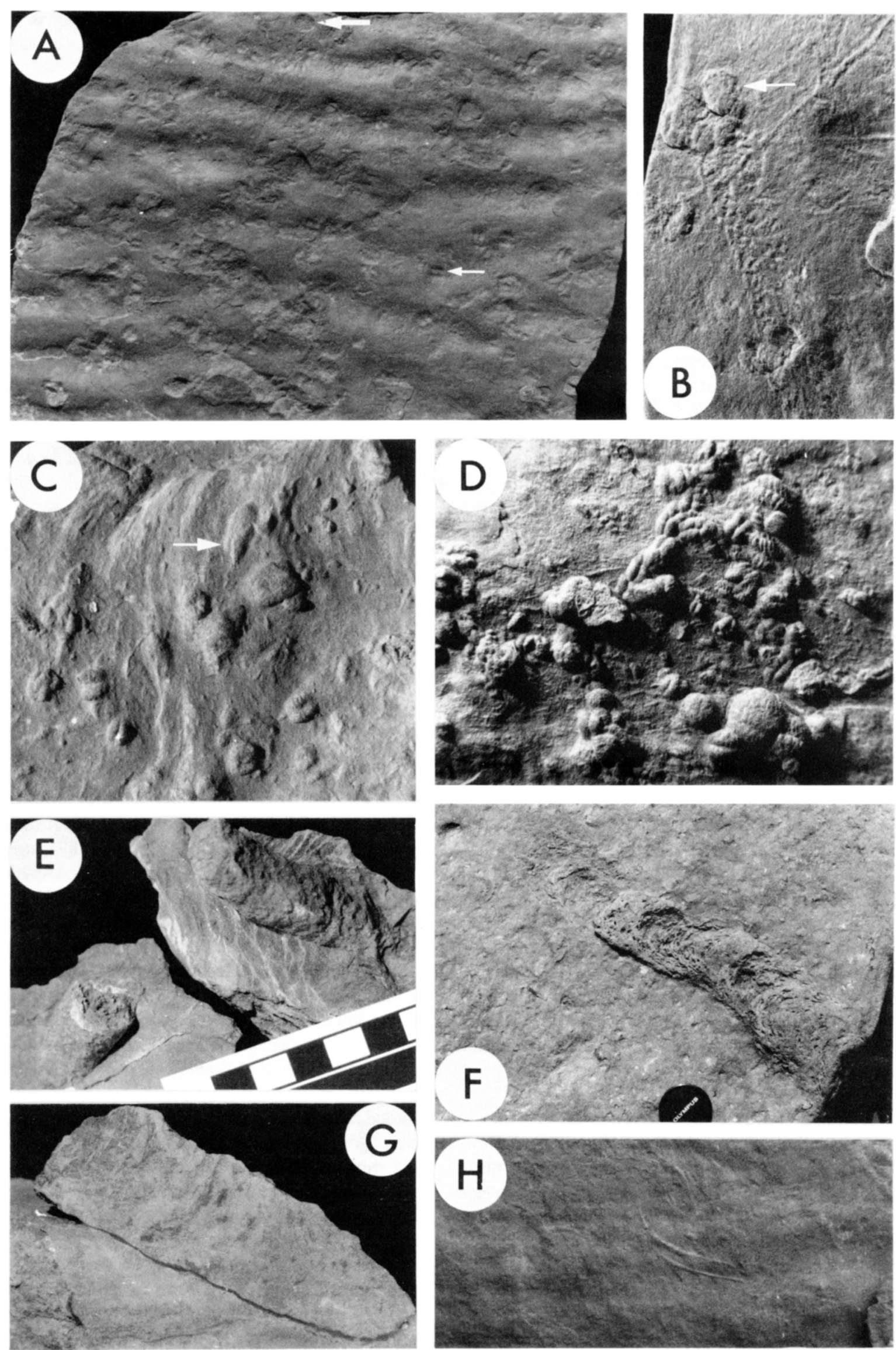
bilobate. However, these structures from TF0 la are of similar width $(4-5 \mathrm{~mm})$ to other rusophycids found in the same area (e.g., TF02d).

Remarks: Assignment to Rusophycus is provisional because it is not certain whether the material is truly bilobate. One specimen is similar to one of the morphologies originally included in 'Isopodichnus' (nom. catastroph.) eutendorfensis by Linck (1942).

\section{Ichnogenus Selenichnites Romano and Whyte, 1990}

Diagnosis: Shallow, suboval trace occurring isolated or in series, slightly wider than long. A strongly convex, lunateshaped lobe, or paired and opposing crescent-shaped lobes, demarcate(s) the (posterior) margin that opposes the rounded (anterior) margin. Striae and, or, a (posterior) ridge may be present (modified from Romano and Whyte, 1987).

Type ichnospecies: Selenichnus hundalensis Romano and Whyte (=Selenichnites hundalensis Romano and Whyte), by original monotypy.

Nomenclatural discussion: The original name provided for this trace fossil was later found to have already been utilized for a vertebrate trackway by Hitchcock (1858), and hence it was invalidly introduced as a junior homonym (Romano and Whyte, 1990). In the original discussion of the ichnogenus, Kouphichnium rossendalensis Hardy and Kouphichnium cordiformis Fischer were considered synonymous, though as distinct ichnospecies. Guanzhong (1993) has provided the only other reference of this ichnogenus to date.

\section{Selenichnites isp. Figure 7B}

Description: One specimen, forming part of TF01a, is preserved as a subdued convex hypichnion, $10 \mathrm{~mm}$ long by 14 $\mathrm{mm}$ wide, on a wave rippled, fine-grained sandstone and forms part of a compound structure with a specimen of Protichnites cf. kennediea. It resembles squat, paired sycamore seeds, the 'wings' being unornamented ovate mounds, the actual 'seeds' being smaller, more rounded mounds that attach to the $P$. cf. kennediea trackway.

Remarks: The material described herein is very similar in form to that of the holotype of the type ichnospecies. However, since the holotype is much larger $(140$ by $170 \mathrm{~mm})$, with considerably more relief and a central mound between the 'wings', it has not been included within that ichnospecies. $S$. rossendalensis is more ungulate in form.

\section{Ichnogenus Taenidium Heer, 1877}

Emended diagnosis: Unwalled, essentially cylindrical, meniscate, backfilled burrows. Variably oriented in a straight, winding, curved, or sinuous pattern. Secondary successive branching may occur, but true branching is absent (after Keighley and Pickerill, 1994).

Type ichnospecies: $T$. serpentinum Heer, by subsequent designation (Häntzschel, 1962).

Nomenclatural discussion: The nomenclatural debate, and reasoning behind the assignment of our material to this ichnogenus, follows D'Alessandro and Bromley (1987) and Keighley and Pickerill (1994): wall linings are not present in Taenidium, distinguishing it as an unwalled ichnotaxon, and ichnospecies are defined by variations in the style of meniscate fill - the fill being variably compartmentalized, and of homogeneous or heterogeneous, faecal and nonfaecal content. We include Beaconites barretti Bradshaw as T. barretti, because it is unlined (hence unwalled) and consider the type ichnospecies; Beaconites antarcticus Vialov, to be walled. Goldring and Pollard (1995, p. 675) criticized the fact that we did not examine topotype material of Beaconites in arriving at our decision regarding the use of this name but there was absolutely no reason to do so (see Keighley and Pickerill, 1996b). Therefore, our recommendation that Beaconites (by way of the type ichnospecies) be utilized for walled burrows was based on our interpretation of Vialov's (1962) diagnosis and figures - the only valid material that there was to consider - and subsequent use of $B$. antarcticus for lined burrows (e.g., Bradshaw, 1981, p. 630). Unfortunately, the diagnosis of Beaconites does not explicitly state that a lining is absent or present and, as stated, no valid type material exists to confirm this (contra Goldring and Pollard, 1995, 1996).

If the cipher 'Beaconites' were to be used for unlined burrows, as advocated by Goldring and Pollard (1995), the cipher becomes a junior synonym of Taenidium since, following D'Alessandro and Bromley (1987), meniscate burrows without a wall lining should be included within Taenidium. Furthermore, in following Goldring and Pollard's (1995) approach, meniscate burrows with a wall-lining would be left without a name - as Keighley and Pickerill (1994) have argued, Ancorichnus Heinberg cannot be used. Our approach avoids these problems. However, Goldring and Pollard (1995) would still be free to consider Beaconites distinct as an unwalled burrow if they could adequately differentiate it from the currently accepted definition of Taenidium, or wished to further modify this latter definition (and perhaps suggest a new name for walled meniscate burrows). This they have failed to do, stating only that there was a 'possible' distinction in the nature of the menisci: menisci are regularly spaced in Taenidium serpentinum Heer, $T$. satanassi D'Alessandro and Bromley, and $T$. cameronensis (Brady), but not in the barretti ichnospecies. However, spacing of the menisci had previously been considered an accessory criterion to differentiate ichnospecies, rather than a significant criterion to differentiate ichnogenera, by D'Alessandro and Bromley (1987). Furthermore that the barretti ichnospecies does not show regular spacing is no reason to suggest that Beaconites be differentiated on the basis of irregular spacing. The barretti ichnospecies is not 
the type of the ichnogenus Beaconites and so has no relevance to what the cipher Beaconites represents, and one feature that is categoric in the type ichnospecies, $B$. antarcticus, detailed in Vialov $(1962$, p. 628 and fig. 9), is that it does have very regular spacing. Goldring and Pollard (1995) also noted that Taenidium is typically (but not exclusively) 10 $\mathrm{mm}$ or less in diameter, but elsewhere acknowledged that size is not a suitable ichnotaxobase. We concur with them that environment is not a valid ichnotaxobase (Keighley and Pickerill, 1994, p. 308; Keighley and Pickerill, 1996c).

\section{Taenidium barretti (Bradshaw, 1981) Figure 7E, 7F, 7G}

Emended diagnosis: Straight to variably meandering, unbranched, unwalled, meniscate backfilled burrow. Menisci are commonly hemispherical or deeply arcuate, tightly packed or stacked, forming noncompartmentalized backfill or thin meniscate segments (after Keighley and Pickerill, 1994).

Description: The material from TF03a is preserved on all faces of collected slabs, due to extensive burrowing. These eleven specimens may be preserved either as exichnia or endichnia. Inclined burrows (up to $30^{\circ}$ from the vertical) predominate. Preserved shafts have crenate outer surfaces (Fig. 7E), and diagenetic alteration of the outer parts of some burrow fills can give a false impression of a pelletal wall, potentially causing confusion with Ophiomorpha irregulaire Frey et al. (cf. Goldring and Pollard, 1995). Sectioning confirms that no wall is present and that the fill comprises heterogeneous meniscate segments or heterogeneous, noncompartmentalized fill. Small angular clasts of mudstone commonly best define the meniscate fill. Menisci may indicate movement to have been both upward (Fig. 7G) and downward (Keighley and Pickerill, 1994, text-fig. 6C) in vertical and inclined specimens. They are all preserved in a veryfine-grained sandstone that contains climbing-ripple crosslamination. Numerous top and bottom surfaces of slabs, in contact with laminated mudstone, display evidence of desiccation cracks.

The $>100$ specimens of TF03f and TF03 $g$ are preserved in 35 to $70 \mathrm{~mm}$ thick slabs of current rippled, very-fineand fine-grained sandstone. The slabs are pervasively burrowed and vertical, inclined, and horizontal specimens can be observed on the top, side and bottom faces of the slabs though (sub-) vertically oriented specimens predominate (Keighley and Pickerill, 1994, text-fig. 6D). Burrows range in diameter from 3 to $21 \mathrm{~mm}$ (Fig. 8). Burrows have weathered at a similar rate to the host rock and little or no relief is present. The fill is typically darker in colour than the host sediment, well sorted, and of finer grain size. This results in subtle menisci distinguishable only in sectioned material. Similar looking specimens (TF35a), visible only on top surfaces in outcrop, are provisionally included within the ichnotaxon.

One specimen was observed (but not collected) as TF28a. This burrow was much larger, with a diameter of $75 \mathrm{~mm}$ (Fig. 7F) and although the fill was highly heterogeneous, no distinct compartments were noted. Menisci were typically highly arcuate and locally deeply inset. The burrow undulates slightly from the horizontal until the point where it sharply disappeared into (or appeared from) the preserving stratum of poorly sorted, horizontally laminated, medium-grained sandstone. A single, shallow, bowl-shaped depression of $\sim 6 \mathrm{~mm}$ diameter was also present on the same surface and likely is part of another, vertically oriented specimen.

Remarks: Most previously described specimens assigned to this ichnotaxon are from distinctively nonmarine environments (Keighley and Pickerill, 1994, text-fig. 5) and are of large size (up to $450 \mathrm{~mm}$ width - Pearson, 1992). In contrast, recorded widths (but not necessarily diameters - Graham and Pollard, 1982) may be as small as $3 \mathrm{~mm}$ for one specimen from TF03f (Fig. 8); only the specimen from TF28a (Fig. 7F) readily invites comparison with the 'classical' concept of the barretti ichnospecies. However, there is a continuous gradation in sizes between recorded specimens in the literature (Keighley and Pickerill, 1994, text-fig. 3), and ichnotaxonomical distinction of the more abundant smaller specimens of this study is not warranted. The size distribution of the burrows in TF03f and TF03g exhibits an approximately normal distribution. Since trace fossils cannot undergo selective sorting by transport, and since small burrows may postdate larger burrows, there was most likely a normal distribution in the size of the producers.

The identity of the animal(s) responsible for the production of T. barretti remains conjectural (Brück, 1987). A producer with a short body length might be favoured by evidence of minor lateral offsets of individual menisci (Graham and Pollard, 1982). Arthropods (e.g., Pollard et al., 1982), bivalves (e.g., Pryor, 1967; Gordon, 1988), and, or, vertebrates may have produced the structures from western Cape Breton Island. Rolfe (1980) suggested that arthropods may have produced an open burrow system and that the menisci were due to passive infilling. As pointed out by Allen and Williams (1981, also see Fig. 7G), horizontal and downwardfacing menisci rule out an open burrow scenario, but not necessarily an arthropod origin. In adjacent strata to many of the $T$. barretti specimens, was found a single, relatively large Cruziana problematica (TF03b) of similar diameter to many of the $T$. barretti burrows. This might suggest that both ichnotaxa may have been produced by arthropods. Similarly, the diameter of subvertical burrows tentatively attributed to T. barretti (TF35a) corresponds to the width of Hexapodichnus trackways (of assumed arthropod origin) that occur some $15 \mathrm{~m}$ further upsection (TF36). The producer of the specimen in TF28a.

\section{cf. Taenidium}

Figure 9A, 9B

Description: Preserved hypichnially and in full relief on the base of a fine-grained sandstone, this solitary specimen, which forms part of TF24a, is very much a flattened cylindrical burrow, $12 \mathrm{~mm}$ wide by $4 \mathrm{~mm}$ high in transverse cross- 


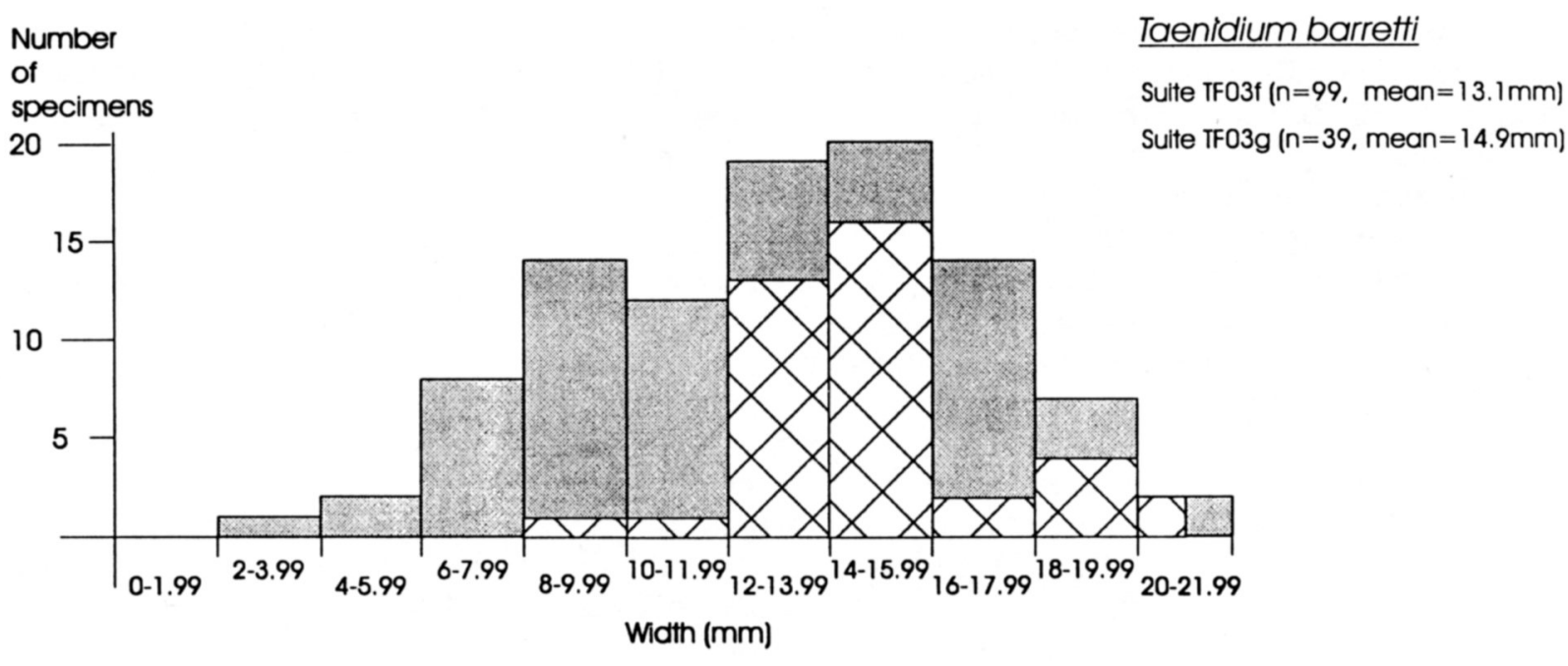

Fig. 8. Size distributions of specimens of Taenidium barretti in the present study. Burrow widths from TF03f are shown as the solid columns, burrow widths from TF03g are shown as the cross-hatched columns.

section. The burrow has a vague, irregularly shaped and spaced, meniscate fill when seen in vertical longitudinal section. Mostly the fill is finer grained and darker in colour than the preserving strata. No wall structure is present. In hypichnial plan view it is gently and irregularly curving in form.

Remarks: Though the presence of menisci and the lack of a wall are characteristics of Taenidium, the irregular nature of the menisci, both in frequency and shape, are not fully consistent with the diagnosis of this ichnotaxon, and therefore assignment is tentative.

\section{Ichnogenus Thalassinoides Ehrenberg, 1944}

Diagnosis: Burrow systems typically with both vertical and horizontal elements, walled or unwalled, but with smooth external surface. Burrows cylindrical, branching regular and characterized by Y-shaped bifurcations, swollen at the point of branching at least for unlined specimens. Horizontal elements occasionally join to form polygons. Burrow diameters variable within a system (after Kennedy, 1967).

Type ichnospecies: Thalassinoides callianassae Ehrenberg, by original designation (=Thalassinoides suevicus?, Kennedy, 1967).

Nomenclatural discussion: As emended by Kennedy (1967), to avoid confusion with other ichnotaxa of branching burrow networks, Thalassinoides should contain bifurcations that are swollen at the point of branching, and a smooth, unornamented burrow boundary. A wall lining may or may not be present, but pelletal or skeletal wall constructions are absent. Four ichnospecies were described by Kennedy (1967) but, following the attempted revisions of Fürsich (1973), the work on Ophiomorpha by Frey et al. (1978), and the consensus to retain Spongeliomorpha Saporta (e.g., Ekdale et al., 1984), only $T$. suevicus (Rieth) and $T$. paradoxicus
(Woodward) were retained as valid ichnospecies. These are differentiated by $T$. suevicus having regular Y-branching and regular burrow diameters within individual specimens, whereas $T$. paradoxicus has irregular burrow diameters and less regular branching. Howard and Frey (1984), Frey and Howard (1985), and Frey and Bromley (1985) have each described T. suevicus as having 'predominantly' Y-shaped branches; $T$. paradoxicus has 'predominantly' $T$-shaped branches.

However, four other ichnospecies of Thalassinoides have subsequently been introduced. T. tandoni Badve and Ghare was considered by its authors comparable to but, at $15 \mathrm{~mm}$ burrow diameter, much smaller than $T$. saxonicus (Geinitz). A one-dimensional size parameter is a very poor ichnotaxobase (Pickerill, 1994), and T. saxonicus is now considered to be a junior synonym of Ophiomorpha nodosa Lundgren (Frey et al., 1978). Frey et al.'s (1978) $O$. nodosa had burrow diameters of less than $20 \mathrm{~mm}$, and so $T$. tandoni can be readily included within it as a junior synonym. T. minimus Aron was vaguely defined with only a general accompanying photograph of the holotype and should best be considered a nomen dubium. T. foedus Mikuláš is similar to $T$. suevicus, being mostly horizontal with Y-shaped branches, and mostly a smooth outer boundary. In places however, $T$. foedus contains oblique scratch marks, comparable with Spongeliomorpha. It is therefore a compound specimen, in part assignable to $T$. suevicus and in part to Spongeliomorpha isp., and not worthy of a new ichnospecies name. Thalassinoides is distinguished from Paleodictyon on the basis of the former having swellings at the points of bifurcation (Kennedy, 1967). However, the recently introduced $T$. horizontalis Myrow lacks such swellings (nor are any vertical elements preserved) but has a thick, diagenetically altered wall lining, and it is this latter feature that Myrow (1995) used to differentiate the two ichnogenera. Though Myrow's summary emphasizes only very regular size, uniform small diameter and horizontal orientation, which does not adequately distinguish the structure from $T$. suevicus (all the mentioned ichnotaxobases are in- 

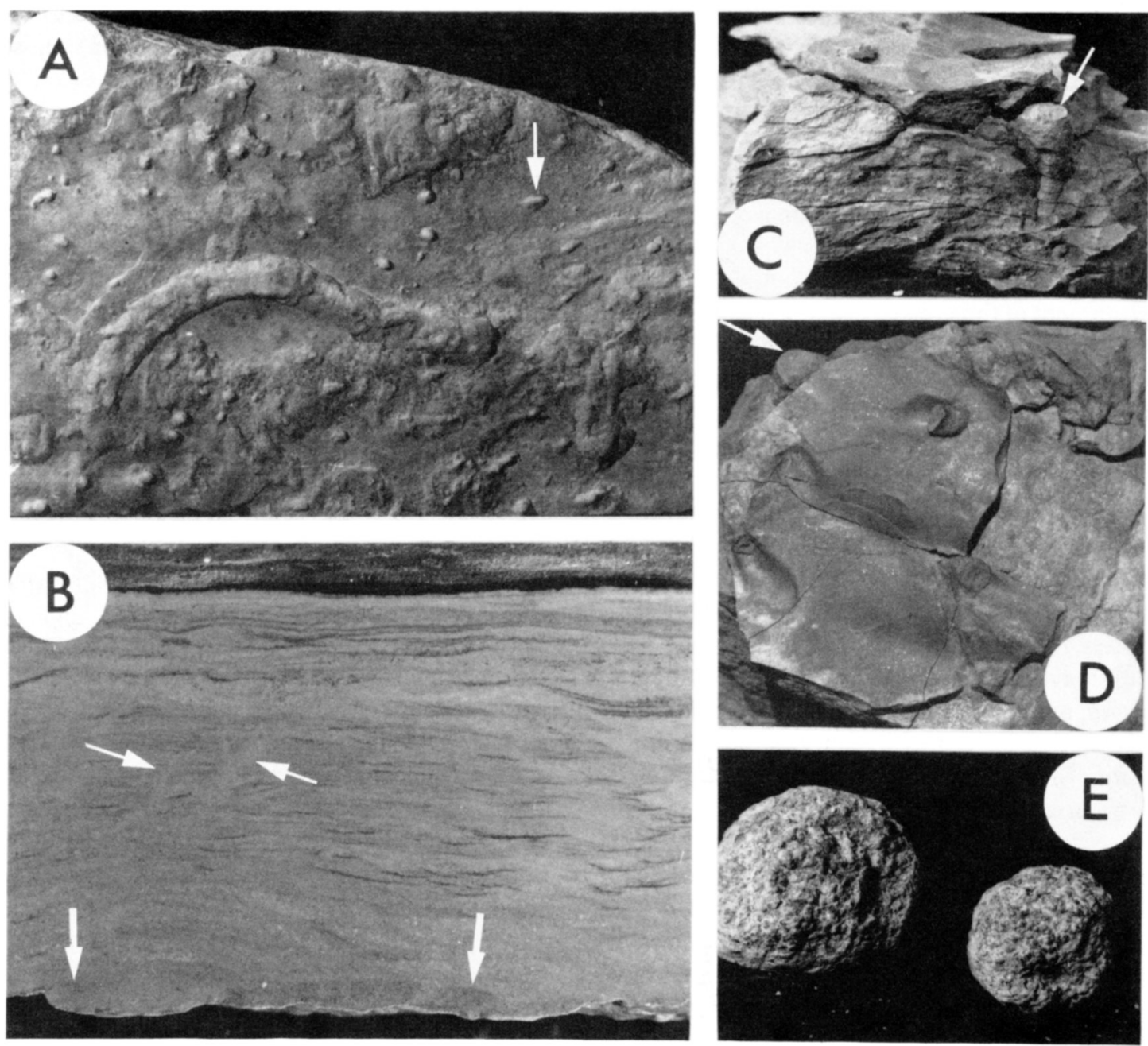

Fig. 9. $\mathrm{A}=$ cf. Taenidium and small ovate pits, type $\mathrm{C}$ (example arrowed), as convex hypichnia, from TF24a (mag. $\mathrm{x} 0.45$ ). $\mathrm{B}=$ Vertical cross-sectional view of cf. Taenidium and vertical 'escape' structures shown in Figure 9A (mag. $x 1.0$ ) - the burrow (cf. Taenidium) is present at the bottom centre to bottom left (large arrows). The vertical 'escape' structures illustrated by small arrows are examples somewhat oblique to the vertical. $C=$ Thalassinoides suevicus, preserved endichnially, from TF10a (mag. $\mathrm{x} 1.0$ ). $\mathrm{D}=$ Top view of part of the Thalassinoides suevicus shown in Figure 9C (mag. $x$ 1.0) - vertical burrow and chamber shown in Figure $9 \mathrm{C}$ are arrowed. $E=$ Excavated coprolites from TF27a (mag. x 0.9).

adequate), the ichnospecies is potentially useful. The lack of swellings at both T- and Y-shaped bifurcations and a thick lining are unique features.

In his emended diagnosis, Kennedy (1967) explicitly stated that Thalassinoides burrows were between 20 to 200 $\mathrm{mm}$ diameter. However, this comment has subsequently been removed from the diagnosis, as much smaller diameter burrows have been described. For example, Frey and Howard (1985) described T. suevicus 'segments' of 9 to $15 \mathrm{~mm}$ diameter. The specimen identified in this study is even smaller, having a compactionally deformed burrow diameter of between 3 and $4 \mathrm{~mm}$.

Thalassinoides suevicus (Rieth, 1932) Figure 9C, 9D

Diagnosis: Predominantly horizontal, more or less regularly branched, smooth surfaced, essentially cylindrical components forming large burrow systems; dichotomous bifurca- tions more common than T-shaped branches (after Frey and Howard, 1985).

Description: One three-dimensional, branched, burrow system is represented in TF10a. A vertical shaft, width $>4 \mathrm{~mm}$, widens into an $\sim 8 \mathrm{~mm}$ wide swelling, almost chamber-like, from which two branches $(\sim 4 \mathrm{~mm}$ wide) bifurcate at approximately $90^{\circ}$ to each other and continue upward at approximately $20^{\circ}$ to the 'horizontal' (as defined by parallellaminations in the preserving stratum of siltstone). One of the branches curves gradually so that, in plan view at the top of the sample, the two burrows describe an angle of only $60^{\circ}$ from their point of bifurcation. A possible, now weathered away, third branch may extend from the same swelling at a high angle to the 'horizontal' and in the opposite direction to the other branches. Three other burrows of similar diameter (when compactional deformation is taken into account), inclined $\sim 45^{\circ}$ to the horizontal, are present in the same specimen. These burrows are each from separate points 
of bifurcation, only one of which is visible as a $7 \mathrm{~mm}$ wide swelling. The burrow system is present in a parallel-laminated, relatively micaceous siltstone with a thin sheen of mudstone that forms part of a thick, variegated, laminated mudstone body. The burrow fill, assumed to have been passively accumulated, is of the same composition as the host stratum. No wall is present, and the burrow boundary is distinctly smooth and lacking in striae.

Remarks: Assignment of the present specimen to $T$. suevicus rather than T. paradoxicus is based upon the lack of ornamentation (scratch marks, etc.) on the burrow surfaces, the presence of swellings at the points of bifurcation, the regularity in burrow widths away from these swellings, and the lack of observed T-branches. The vertical aspect to the burrow system and the lack of any wall distinguishes it from $T$. horizontalis. The mostly endichnial production and preservation has meant minimal taphonomic modification by weathering or erosion. The fine-grained nature of the host sediment also implies that if surface ornamentation had been present, it would have been preserved. Thus, assignment to Spongeliomorpha, as part of a taphoseries, need not be considered. The specimen is, however, marginally smaller in burrow diameter than previously recorded examples of Thalassinoides, particularly $T$. suevicus. A 7 to $15 \mathrm{~mm}$ diameter burrow recorded by Frey and Howard (1990) appears to be the previous smallest burrow diameter recorded for this ichnospecies, although McCann and Pickerill (1988) noted material, assigned as Thalassinoides isp., to be 6 to $10 \mathrm{~mm}$ in diameter. Frey and Howard (1985), however, have described 'junior' Thalassinoides-type burrows produced by present-day juvenile shrimps.

Ekdale and Bromley (1984) noted that burrow systems of Thalassinoides tend to decrease in size as the sediment becomes compacted and gradually lithifies (i.e., the substrate passes from a softground to a firmground and eventually to a hardground). This might suggest that the material forming TF10a was produced in a firmground setting. However, Ekdale and Bromley (1984) also suggested that as the burrows become smaller, they also become more stenomorphic (i.e., irregular in outline) whereas the present specimen appears, despite limited preservation, to be regular in form. $T$. suevicus has previously been stated to be predominantly horizontal in form, unlike the distinctly three-dimensional network of the specimen described herein. The swellings are also particularly pronounced in TF10a, being twice the diameter of the burrow shafts and tunnels, in contrast to the slight swellings most commonly seen (e.g., Frey and Howard, 1985, figs. 19.1, 24). Indeed, it may be more accurate to call the swellings 'chambers' because of their predominance. Finally, as the origin of the name implies, a limbed arthropod (specifically a thalassinidean shrimp) is invoked as a primary producer of this trace fossil (e.g., Frey and Howard, 1985). An open burrow system is unlikely to be retained in a fine-grained softground without, at least, a mucous lining having been produced. Arthropods do not produce mucous linings (Frey et al., 1984) and so a firmground origin would be favoured, but if this was the case, then it might be ex- pected that a striate ornament, the result of the original excavation of the burrow by its arthropod producer, should be preserved (e.g., as in Ridgley's, 1989, lacustrine 'Thalassinoides' = Spongeliomorpha). Alternatively, Myrow (1995) has invoked limbless organisms as producers of his Ordovician material (since the material considerably predates the fossil record of decapods). A similar, possibly vermiform producer is suggested for the TF10a material: the presence of an elongate body may have been what necessitated the production of a wide swelling at the bifurcation points so that the organism could turn around.

Thalassinoides has been described from a variety of environmental settings. At the ichnospecies level, $T$. cf. suevicus has been interpreted to be from fluvial distributary channel deposits and alluvial swamp and brackish tidal flats (see Keighley, 1996, unpublished Ph.D. thesis, for examples).

\section{Ichnogenus Undichnus Anderson, 1976 (nom. correct.)}

Emended diagnosis: Negative epirelief or positive hyporelief interface trails comprising two or more distinct, sinuous trails with a common wavelength and alignment, and with or without an accompanying straight furrow/ridge upon which the waves are superimposed. Waves continuous or discontinuous, typically occurring in combinations, or exclusively, of parallel pairs, nonparallel intertwined pairs, or nonparallel separate pairs; unpaired waves may also occur in combination (emended from Anderson, 1976, and Higgs, 1988).

Type ichnospecies: Undichna simplicitas Anderson, by original designation.

Nomenclatural discussion: Anderson (1976) originally introduced the name as Undichna, Smith (1987) correctly (I.C.Z.N., Article 26, 30a.iii) used the name Undichnus, since according to Anderson (1976, p. 400), the name derives from 'Unda -ae f. (Latin) = wave + ichna' but 'ichnus' is the noun and is masculine. Like Circulichnus, the type ichnospecies remains fixed in its original spelling as Undichna simplicitas (I.C.Z.N., Article 67d), but when used to describe specimens, the corrected spelling (in the masculine) is adopted, that is, Undichnus simplicitus. Similarly all the other ichnospecies that were introduced with feminine endings have to be corrected to the masculine: $U$. binus Anderson, $U$. insolentius Anderson, $U$. britannicus Higgs, and $U$. consulcus Higgs.

The original 'definition' (=diagnosis) was also inconsistent, describing the ichnogenus as having a set of distinct waves with a common wavelength, though the type ichnospecies was noted to have 'sets' within a complete 'set'. It was also erroneously stated that a set of waves had more or less bilateral symmetry (they were in-phase). Higgs (1988) clarified this latter situation, noting that individual waves of the set may be parallel but not bilaterally symmetrical. In the original diagnosis, Anderson (1976) also stated that, occasionally, only one wave may be present, though in the discussion this is countered with the comment: '...[i]f none but isolated waves are encountered at a locality, and espe- 
cially where these are sinusoidal, identification as Undichna is unwarranted (cf. ichnogenus Cochlichnus Hitchcock 1858)...' (Anderson, 1976, p. 400). This contradictory note in the diagnosis was not corrected by Higgs (1988); hence the emended diagnosis given above.

Anderson (1976) considered that where more than one wave was present, Undichnus could not be confused with any other ichnogenus, citing Hantzschel (1962) as the reference in which no comparable forms were noted. Häntzschel (1975), however, did note the existence of Cochlea Hitchcock, that has an intertwined wave pair, but he considered the name invalid as a junior homonym (but without elaboration).

Anderson (1976) introduced three ichnospecies. $U$. simplicitus was defined as having two sets of paired waves, one pair sinusoidal, one pair scalloped (convex outward), and one unpaired wave in a complete set. However, her textfig. 2D and pl. 54.4 were also described as $U$. simplicitus even though only a repetitive set of transverse sigmoids was illustrated in both cases. Such a form is a highly distinctive morphology, most certainly not Undichnus as diagnosed by Anderson (1976). Neither does the form preserve a complete 'sine' wave to permit inclusion in Cochlichnus; a new name is required for this specimen. $U$. binus was defined as having only one pair of parallel, sinusoidal waves and no unpaired wave, whereas $U$. insolentius was defined as having two or three pairs of sinusoidal waves, a scalloped pair, and an unpaired wave. Why a specimen with one pair, and a specimen with two pairs, of sinusoidal waves were considered to warrant separate ichnospecies names, but specimens with two or three paired sine waves were considered to be of the same ichnospecies, was not explained. Indeed, it was noted that specimens of $U$. simplicitus might have been badly preserved $U$. insolentius (Anderson, p. 402). Accordingly, $U$. insolentius is probably best considered a junior synonym of the type ichnospecies, and any number of paired sine waves can be included within the type.

Higgs (1988) introduced two useful new ichnospecies of Undichnus: $U$. britannicus and $U$. consulcus. $U$. britannicus contains two intertwined, complete waves, the description also noting the occasional presence of an incomplete outer scalloped (convex inward) pair. U. consulcus contains a shallow, wide, and unornamented central furrow that is straight to gently curving, superimposed on which are a pair of (or, it might be argued, one) complete or incomplete (intertwined) wave(s). Higgs' (1988) illustrations of $U$. simplicitus are of incomplete specimens that could equally be Cochlichnus or Helminthopsis.

Turek (1989) introduced $U$. radnicensis as a morphologically 'highly variable' form that could resemble $U$. britannicus and $U$. binus. Indeed, one of his simplified drawings (text-fig. 2a, and pl. 73.2), an intertwined wave pair with outer scallops, appears to represent only a minor variant on $U$. britannicus; his text-fig $2 c$ and text-fig. 4 are identical to $U$. binus but for a slight feathering on one of the waves, and his pl. 73.1 might have a straight, shallow central groove (possibly $U$. consulcus). Several other forms that are distinct were also illustrated and included under the catch-all
$U$. radnicensis (which, being polymorphic, should therefore be considered a dubious ichnospecies in need of reassessment).

A final problem with the original introduction of this ichnogenus was its inclusion within the zoological class Pisces. Trace fossils do not enter into zoological Linnean classifications, and it is reiterated that the same trace may be produced by animals of different phylogenetic origins (Pickerill, 1994). This probably led to the superfluous introduction of two new ichnospecies of the ichnogenus Lunichnium Walter, namely $L$. gracile Turek and $L$. anceps Turek. Lunichnium is a trackway with longitudinally oriented, lunate striae that can be readily interpreted as the swimming trackway of a podous vertebrate. The holotype of $L$. gracile was illustrated (Turek, 1989, text-fig. 6A) as a pair of subparallel sine waves in association with tetrapod footprints, and also as only a pair of subparallel sine waves exclusive of footprints (Turek, 1989 , text-fig. 6B-C). The latter may just as easily have been produced by a fish. $L$. gracile, and $L$. anceps (differing from L. gracile only in size), can be considered junior synonyms of $U$. binus. To date, virtually all occurrences of Undichnus noted at both the ichnogeneric and ichnospecific level are from lacustrine environments.

\section{Undichnus binus Anderson, 1976 (nom. correct.) Figure 2C, F}

Diagnosis: One pair of parallel, in-phase, sinusoidal waves in concave epirelief or convex hyporelief (after Anderson, 1976).

Description: Preserved in concave epirelief in the same assemblage (TF26b) as $U$. consulcus (see below), this single specimen is of limited extent, and the in-phase pairing of waves is only notable over part of the trail where the more distinct, longer sine wave has its shorter wavelengths. Only 3.5 complete waves are present even on the longer, $45 \mathrm{~mm}$ long wave, where wavelength varies from 12 to $16 \mathrm{~mm}$, whereas the amplitude averages $5 \mathrm{~mm}$. Maximum separation of the two waves is $\mathbf{4} \mathrm{mm}$. Individual grooves are never more than $2 \mathrm{~mm}$ wide.

Remarks: This is a simple trail, typical of the ichnospecies.

\section{Undichnus consulcus Higgs, 1988 (nom. correct.) Figure 2C}

Diagnosis: A simple, straight to slightly curving, unornamented furrow with one, or more than one intertwined, sine waves superimposed (after Higgs, 1988).

Description: The only specimen, from TF26b, is a deeply furrowing, virtually continuous, sinusoidal groove, locally paired with another faint sinusoidal groove, and is present epichnially on the surface of a wave rippled, fine-grained sandstone. The continuous sinusoidal groove is of variable width (1-3 mm), with the outer margin at some apices rucked up to form a small ridge. It overprints a rather narrow (1-2 
$\mathrm{mm}$ wide), relatively straight groove that is variably excentric to the axis of the sinusoidal groove. A significant, sharp change in direction occurs at approximately the midpoint (lengthwise) of the trace, on the other side of which the paired, sinusoida, and central, grooves are absent. The amplitude of the sine wave is between 10 and $15 \mathrm{~mm}$, and the wavelength varies between 30 and $35 \mathrm{~mm}$. The base of the grooves locally retain remnant mudstone from the overlying strata.

Remarks: In comparison with the holotype and paratypes of $U$. consulcus, the central groove of the TF26b specimen is comparatively narrow and deeper, whereas the overprinting wave is more continuous and in most cases thicker. However, the general form is readily comparable with the holotype.

As suggested by Higgs (1988, p. 265, text-fig. 6), the trail can be readily associated with the swimming movement of a bottom-feeding fish.

\section{cf. Undichnus isp. Figure 7H}

Description: The one specimen encountered, from TF07a, comprises two arcuate ridges preserved hypichnially on the base of a diffusely low angle cross-laminated, very-fine-grained sandstone that overlies rippled, silty, very-fine-grained sandstones. The ridges are $1.5 \mathrm{~mm}$ at maximum width and between 1.5 and $3 \mathrm{~mm}$ apart.

Remarks: Assignment to Undichnus is provisional because less than one complete sine wave is present for each of the waves, and the specimen could even be a pseudofossil (e.g., a tool mark). If assignment to Undichnus were to be accepted, since the two waves seem neither to be in phase, nor to be entirely parallel, assignment to $U$. binus is unwarranted. Instead, the inference is that the two waves would intertwine if the trace was more complete, and hence there is a closer affinity to $U$. britannicus.

\section{Coprolites}

Figure 9E

Description: The four specimens, all from TF27a, are a dark grey colour, subspherical, between 15 and $29 \mathrm{~mm}$ in longest diameter, and are composed of many dozens of small agglutinated pellets. In thin section, these pellets are sideritized, displaying saddleback extinction in crossed-polars indicative of spherosiderite (pellets are ubiquitously of less than 4 $\mathrm{mm}$ diameter). They were found weathering out of a massive, very soft claystone that underlies a $0.5 \mathrm{~m}$ sandstone with abundant plant detritus.

Remarks: Such coprolitic structures as encountered herein have not been definitively recorded by other workers. Major (1939) and Amstutz (1958), from the Tertiary of Washington State, U.S.A., noted similar sized coprolites with comparable external, pelleted ornament, though internally the coprolites were composed of microcrystalline siderite. Lensch (referred to by Häntzschel et al., 1968), from the
Early Permian of Germany, described 20 to $50 \mathrm{~mm}$ diameter ellipsoidal coprolites composed of sphalerite, galena, and dolomite or siderite, and Bayer (also see Hăntzschel $e t$ al., 1968) described Upper Carboniferous coprolites from Czechoslovakia that were sphaerosideritic in composition size and form were not noted.

\section{Interface trails}

Nomenclatural discussion: No suitable ichnotaxon currently exists to accommodate the three types of interface trails, and their intermediate forms that are recognized herein. Accordingly, they are described in open nomenclature.

\section{Interface trail, type $A$ Figure 10B, 10C}

Description: Most of the 18 specimens recovered are present as epichnia on a thin $(<5 \mathrm{~mm})$, horizontally laminated, veryfine-grained sandstone (TF03c). The trails consist of narrow, typically less than $2.5 \mathrm{~mm}$ wide, straight to slightly meandering, sinuous, or curved ribbons that may be up to $0.12 \mathrm{~m}$ long. On top surfaces, specimens have a central area of subdued, undulating to pustulose relief, almost bead-like in appearance. The pustules are convex-up, typically slightly elongate in a longitudinal direction and may lie either mostly slightly above or slightly below the level of the surrounding strata (Fig. 10B, 10C, respectively). The latter type of pustule preservation is enclosed by lateral margins that are typically defined by a very narrow groove (resembling an irregular tramline). The former type of preservation gives the specimens a slightly annulate appearance. Overprinting the pustules is a virtually continuous groove that may: (a) bisect the bead-like, central structure, (b) lie adjacent to one of the lateral margins (where it may emphasize one of the lateral grooves), or (c) lie outside the main ribbon. Preservation on bottom surfaces results in the preservation of narrow ridges as opposed to grooves, and the pustules appear as depressions. Interface trail type $A$ occurs both as a discrete form and as a compound trace fossil intergradational with interface trail type $\mathrm{C}$.

Remarks: The trace fossils are interpreted as interface trails, as opposed to burrows, because of the groove that overprints the pustulose central part of the ribbon. Such a structure would not be expected to be present in a burrow. The pustulose part of the trail is interpreted to be the result of backfilling of the surface trail by the producer, the groove by the dragging of some posterior part of the animal.

Interface trail type $A$ resembles material and illustrations from fluvial strata noted by Zawiskie et al. (1982, pp. 215-216, fig. 4G-4I) and Chisholm (1985, pp. 620-627, pl. 76.1, 76.3-4). In both cases, the trace fossils were described as, or compared to, Aulichnites, an essentially bilobate structure that may or may not display meniscoid backfill of the lobes, and a unilobate convex undersurface preserved only within the sediment. Most recordings, however, have been of forms with smooth lobes, the convex undersurfaces not having been identified. Vertical sectioning of examples of interface trail 

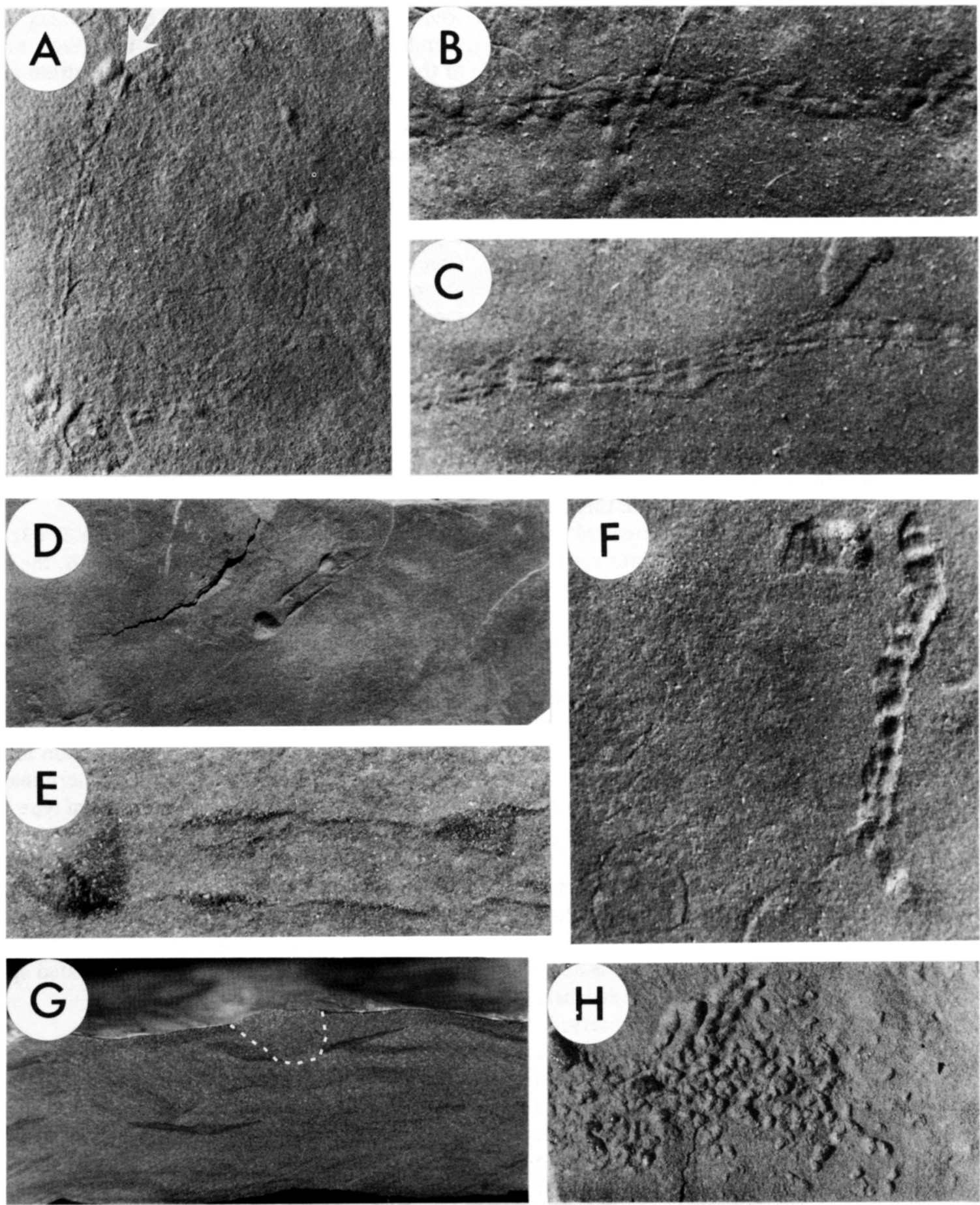

Fig. 10. $A=$ Interface trails, type $C$, and small ovate pits, type A, preserved as compound, convex hypichnia, from TF03c (mag. $X$ 3.0) - the small ovate pit (arrowed) is slightly offset and obliquely oriented with respect to the interface trail. $B=$ Interface trail, type A, from TF03c (mag. $x$ 3.3) - specimen is preserved as an epichnion, the pustulose trail/burrow fill being locally in convex relief. $C=$ Interface trail, type A, from TF03c (mag. $\times 3.4$ ) - specimen is preserved as an epichnion, but in contrast to Figure 10C, the pustulose fill is somewhat subdued and an overprinting, commonly excentric groove is more prominent. $\mathrm{D}=$ Interface trail, type $\mathrm{C}$ (large arrow) and small ovate pit, type A (small arrow), preserved as compound (concave) epichnia, from TF03c (mag. $x$ 1.5). $E=$ Detail of the interface trail, type $C$, and small ovate pit, type A from Figure 10D, with the illumination now from the bottom right (mag. $x$ 6.4). F = Interface trail, type B, preserved epichnially, from TF03c (mag. $\times 3.2$ ) - pustulose trail/burrow fill is distinctly convex and a median groove is only vaguely discernible. An incomplete ?Circulichnus occurs at the bottom left. $G=$ Plug-shaped burrow (outlined), viewed in vertical cross-section, from TF25b (mag. $x$ 1.3) - specimen is asymmetrical, tapering, and present within a flaser-bedded, wave-rippled sandstone. $H=$ Small ovate pits, type $B$, preserved as convex hypichnia, from TF17c (mag. $x$ 1.1). 
type A has been unable to confirm, due to their extremely small size, whether the pustulose material is meniscate in any form, or whether an undersurface is present. However, though an interface trail of type A may appear bilobate where the groove is central to the pustulose backfill, the groove is an overprinting and the structure is not bilobate. The groove may deviate from its central position or it may even disappear where the trail grades into an interface trail of type C.

Chisholm (1985, and references therein) noted and illustrated, under the name Aulichnites? bradfordensis, forms that bear some resemblance to the present material. The material he illustrated was quite diverse in form (frequently forming compound trace fossils) and assignment to one ichnospecies was probably an unwise decision. His questioned ichnogeneric assignment was a wiser, more cautious decision considering the variety of forms that have now been included under Aulichnites. Chisholm (1985) described all of his material as full relief structures with preservation entirely within the sandstone (as endichnia). We would argue that this should not be taken as meaning that none of his 'horizontal' structures were produced at the sediment-water interface in periods between pulses of deposition of monotonous sandy laminations, since full relief structures can be produced at the sediment surface (e.g., Metz, 1987). Of Chisholm's interface (i.e., 'horizontal', non-arrow shaped) structures, several show lateral grooves/ridges with an undulose central 'fill' and central groove/ridge. However, they are consistently bilobate.

Chisholm (1985) considered his material to have been produced by xiphosurids. Present-day recordings of similar traces include those of Chamberlain (1975, fig. 19.2b) who illustrated the trails of dragonfly larvae, and those of Metz (1987, pp. 192-193, figs. 15-16) who noted the presence of other arthropods, notably Phlaeothripidae insects (thrips), associated with narrow surface trails preserved on a drying clay in a present-day ephemeral puddle setting. Where the clay was still saturated with water, a simple groove formed. On drier clays, a more pustulose ribbon was preserved, together with a central to excentric, overprinting groove, likely formed by the tapered abdomen of an insect. Movement of the insect from wetter to drier ground therefore resulted in the production of compound traces. Interface trail type A has been noted as a compound form with interface trail type $\mathrm{C}$, which lacks the overprinting groove, suggesting that an insect producer need not have left its abdomen in contact with the substrate, or alternatively that some other arthropod could elevate its telson from the substrate.

\section{Interface trail, type $B$ Figure 10F}

Description: As with interface trail type A, most of the material recovered (21 specimens) is present on the top surface of a thin ( $<2.5 \mathrm{~mm}$ thick), very-fine-grained sandstone (TF03c). This form of interface trail is similar in width to type A, but the pustulose structures are pronounced and an overprinting groove is intermittent or absent.
Remarks: Though this form is quite distinct in TF03c and therefore is described separately, it is likely only a variant of the previously described form, and ultimately a separation of this form as a distinct ichnospecies may not be warranted. Intermediate forms with moderately pronounced pustulose ornament no doubt will be found by future workers.

Interface trail type B has similarities to material figured by Guerra-Sommer et al. $(1984$, p. 133, pl. 3.1, 3.2) as Gyrochorte. It is uncertain whether their material is indeed an epichnial or hypichnial expression of a full relief structure, since there is no mention of any vertical sectioning that is required to adequately diagnose this ichnogenus. Our material certainly does not exhibit the vertical component required of Gyrochorte.

Interface trail, type $C$ Figure 10A, 10D, 10E

Description: Most specimens are from TF03c ( $\sim 30$ specimens) and, as with interface trail type $B$, the overprinting median groove (that is present in type A) is intermittent or absent. However, the pustulose fill is also only intermittently distinguishable and hence this type forms the third 'end member' of the interface trails. As with interface trail type A, most of the material recovered is present on the top surface of a thin ( $<2.5 \mathrm{~mm}$ thick), very-fine-grained sandstone. One (compound) specimen, is a $2.5 \mathrm{~mm}$ wide, $7 \mathrm{~mm}$ long trail with deep, marginal, V-shaped furrows that terminate (?or commence) in a $2 \mathrm{~mm}$ deep, small ovate pit of type A (Fig. 10D, 10E). Other specimens are present as counterpart hypichnia on a thin sandstone that has a very finely wave rippled, muddy siltstone drape. Transitional, at both ends of another trail, are small ovate pits of type A (preserved as mounds - Fig. 10A). Each 'pit' has its long axis oriented obliquely to the long axis of the trail. One (or two?) isolated specimens are also present in TF03e and TF03d.

Remarks: The form occurs commonly both as a discrete trace and as a compound trace with interface trail type $A$, or with small ovate pits of type A. Since type A trails are interpreted as having formed at the sediment surface, the same interpretation must be given for at least the forms of this morphotype that grade into type A trails. The lack of a central groove in this form results in a passing resemblance to Curvolithus Fritsch, that was illustrated by Eagar et al. (1985) from pro-delta marine strata (though their trace fossil was much larger).

One of the trails that forms a compound specimen with a small ovate pit of type A, most clearly displays marginal grooves that could lead to misassignment under Bilinichnus or Diplopodichnus, and it is only under magnification that the disturbed area between the irregular-margined grooves is distinguished. This small ovate pit likely indicates where the producing organism vertically entered, or exited, the substrate. In this sense it is reminiscent of the 'Beaconichnus darwinum' tramlines of Gevers et al. (1971) that also end 
in elliptical pits. An arthropod appears to be the likely producer, since some specimens intergrade with interface trails of type A, that also likely have an arthropod producer.

\section{Plug-shaped burrows \\ Figures 7A; 10G}

Description: The appearance of these abundant trace fossils on top surfaces of wave rippled, fine-grained sandstones (in TF25b) is simply as a circular to slightly ellipsoidal disc up to $15 \mathrm{~mm}$ in diameter, and typically of different composition to the surrounding rock (e.g., Fig. 7A). Vertical sectioning has revealed the structures to be plug shaped (e.g., $10 \mathrm{~mm}$ diameter and $7 \mathrm{~mm}$ deep), slightly asymmetrical, and with rounded bases (Fig. 10G). Internal structure appears massive.

Remarks: The association of this material on the same slabs as similar sized Rusophycus carbonarius in TF25b (Fig. 7A) may point to an identical producer, the plug-shaped burrows being the result of deeper digging by the arthropod than the surficial etchings that produced $R$. carbonarius. If this is the case, then the base of the plug-shaped burrows should have similar striate marks and a bilobate form. However, their endichnial preservation precludes confirmation of this hypothesis or, for that matter, whether they are more akin to one of the 'plug shaped' ichnotaxa reviewed by Pemberton et al. (1988).

Virtually identical structures have been observed by Pollard and Lovell (1976, e.g., pl. lb and fig. 6b) in ephemeral lacustrine deposits and provisionally referred to Cylindricum (similar material, formed in playa deposits, was thought to be the work of beetles). Häntzschel (1975) considered Cylindricum to be shaped like a test-tube, implying that the plug should be longer (deeper) than it is wide - hence this ichnotaxon should be a candidate for synonymy with Skolithos. However, since the material herein is not shaped like a test-tube, being wider than it is deep, assignment to Cylindricum or Skolithos is not warranted.

\section{Small ovate pits}

Nomenclatural discussion: Three forms of small ovate pits are identified. Their size and shape vary little, the respective forms typically being distinguished by their differing associations with other trace fossils (particularly as compound specimens). Strictly, a fourth form was also encountered but has provisionally been included within Planolites beverleyensis. In addition, the morphology of this group of traces is not otherwise different from the larger plug-shaped burrows, apart from their more ovate appearance in plan view, and intermediate forms may exist.

\section{Small ovate pits, type $A$ Figure 10A}

Description: More than 20, small ( $<4 \mathrm{~mm}$ max. diameter) ovate to subcircular pits are preserved on the top surface of a $5 \mathrm{~mm}$ thick, laminated, very-fine-grained sandstone (TF03c). One specimen occurs as a compound specimen at the end of a specimen assigned to an interface trail of type C. On another slab they are preserved as small ( $<3 \mathrm{~mm}$ long), convex hypichnia (ovate mounds as opposed to pits) and have their long axes oriented obliquely to the long axes of the interface trails, into which they mostly grade as compound forms.

Remarks: Though the preserving stratum for TF03c is thin, the structures do not appear to emerge on the underside of the stratum. This suggests that they are very shallow pits rather than true burrows of any length. The transitional presence of interface trails with many of the pits suggests that they were formed by a vagile animal, likely an arthropod. Their occasional oblique orientation with respect to the interface trails (Fig. 10A) is, however, ethologically enigmatic.

\section{Small ovate pits, type B Figure 10H}

Description: Preserved invariably as hypichnia that form part of TF $17 \mathrm{c}$ and TF17e, in vertical cross-section these abundant trace fossils appear as small, massively filled (i.e., structureless) pits. However, in TF17c, where they are preserved on the base of a locally soft-sediment deformed, fine-grained sandstone, they are occasionally ornamented with fine striae. The pits may be less deep than they are broad, as deep as they are broad, or rarely, deeper than they are broad.

Remarks: Pollard (1981), in assessing similar structures to those noted herein, recognized their resemblance to 'Isopodichnus' (i.e., Rusophycus). In this study, the material from TF17c and TF17e was invariably found alongside examples of Rusophycus, and the structures were probably produced by the same organism as the producer of Rusophycus. But for the fact that Rusophycus is diagnosed as being bilobate, such small ovate pits could be included within that ichnogenus, being of similar size and shape, and occasionally striate. Pollard (1981) suggested that the structures were small cubichnia. This view, if cubichnia also includes concealment traces, is shared herein. The occasional presence of striae on the bases of some of the specimens would indicate that they were produced by a vagile, limbed organism such as an arthropod.

\section{Small ovate pits, type C Figure 9A}

Description: The material, recovered as part of TF24a, is invariably preserved as numerous, shallow, typically $4 \mathrm{~mm}$ by $2 \mathrm{~mm}$, hypichnial mounds on the base of a wave rippled, low angle, cross-laminated, fine-grained sandstone. No preferred orientation of the specimens is noted. Several may be compound specimens with vertical 'escape' burrows.

Remarks: The material vaguely resembles Lockeia but the typical 'almond' shape with a central ridge is not present; 
nor is it unequivocal that the pits form the basal expression of vertical 'escape' burrows. Hence, these trace fossils are retained in the vernacular.

\section{Vertical 'escape' burrows Figure 9B}

Description: At least four, endichnial, vertical, and mostly subvertical structures comprise downward disrupted laminations that otherwise form horizontal and ripple cross-laminations in the preserving, fine-grained sandstone (TF24a). They are 1.5 to $6.5 \mathrm{~mm}$ wide and typically extend for most of the $55 \mathrm{~mm}$ thickness of the sandstone. The disrupted laminations comprise an irregular chevron shape, and typically the ' $V$ ' forms an angle of $60^{\circ}$ to $90^{\circ}$, with the apex of the ' $V$ ' being slightly irregular in location. On the sandstone's base are numerous small ovate pits (type $\mathrm{C}$ ), several of which probably equate to the bases of the vertical structures.

Remarks: No applicable name has been formulated for vertical structures that contain an irregularly chevron-shaped fill, though they have been commonly reported in the literature. They are usually described in an interpretive, ethological sense as 'escape structures' or 'escape burrows'. Whereas similar vertical structures with internal arcuate, ' $U$ '-shaped structures have been included in Taenidium barretti (Keighley and Pickerill, 1994), the irregular, chevron-shaped structures do not correspond with the diagnosis of Taenidium. The basal protrusions of such structures may be compared with Lockeia (see under small ovate pits, type C), but they lack the typical almond-shaped form of this ichnogenus.

The ethological interpretation given in the literature seems perfectly valid for the TF24 structures, that is, they were formed by the rapid, upward migration of a hemisessile surface animal, or mobile subsurface animal in response to a rapid pulse of sedimentation: similar fugichnial structures have been observed adjacent to their (bivalve mollusc) producers (e.g., Berg, 1977; Broadhurst et al., 1980). In the present case, the producers probably were surface dwellers inhabiting normally quiet environments subject to slow deposition, and were able to evacuate to the new surface level following burial by sand (the preserving stratum). Similar 'escape structures' have been identified from various nonmarine environments: fluvial, sheetflood, crevasse splay, and nearshore lacustrine (see Keighley, 1996, unpublished Ph.D. thesis, for examples).

\section{Conclusions}

The trace fossils described herein are from fluvial, lacustrine, and floodplain strata comprising the Mabou and Cumberland groups. Even when the specimens are located within the various formations and members of these groups, they represent a relatively diverse, and likely more complete, representation of Carboniferous nonmarine ichnofaunas than the morphologically similar ichnotaxa encountered elsewhere in the Maritimes (Table 2). Collectively, the Maritime Carboniferous trace fossils are indicative of components of the Scoyenia ichnofacies of Seilacher (1967) and
Table 2. Burrows and trails recorded from Carboniferous nonmarine strata of the Maritimes.

Formations \&

Trace Fossils:

Authors (\&

Assemblage):

Ainslie Formation,

Horton Group -

Western Cape Breton Island

Hamblin, 1989

Strathlorne

Formation,

Horton Group -

Western Cape Breton Island,

Hamblin, 1989

Horton Bluff/

Cheverie formations,

Horton Group -

Windsor area,

Martel and Gibling, 1991

Albert Formation,

Horton Group -

Moncton area,

Pickerill, 1992

Emery Brook

Formation,

Mabou Group -

this work (TF2 la, TF2lb,

TF21c, TF22a, TF22b,

TF23a, TF24a, TF25a,

TF25b)
Lockeia

Rusophycus

Trails

(+ Trackways)

? Bifungites

Cochlichnus

Helminthopsis

Lockeia

Palaeophycus

Planolites

Rusophycus

Scoyenia

Sinall stuffed burrows

(+ Trackways)

Cruziana

Margaritichirus

Palaeophycus

Pelecypodichnus (+Lockeia)

Planolites

Rusophycus

Small stuffed burrows

Cochlichnus anguineus

Cruziana problematica

Gordia marina

Helminthopsis tenuis

$(=H$. abeli $)$

Palaeophycus striatus

Palaeophycus tubularis

Paleodictyon isp.

Planolites isp.

Rusophycus carbonarius

Skolithos isp.

cf. Spongeliomorpha isp.

Vertical escape structures

(+ Trackways)

C.ruziana problematica

Planolites beverleyensis

Rusophycus carbonarius

cf. Taenidium

Plug-shaped burrows

Small ovate pits, type C

Vertical 'escape' burrows

Mermia ichnofacies of Buatois and Mángano (1993), both of which, because of definitions inconsistent with the original ichnofacies concept (Seilacher, 1963, 1964), await revision - which we shall present in a future contribution. 
Table 2 cont. Burrows and trails recorded from Carboniferous nonmarine strata of the Maritimes.

Formations \&

Trace Fossils:

Authors (\&

Assemblage):

Pomquet Formation,

Mabou Group -

this work (TF00a, TF0la,

TF02b, TF02c, TF03a,

TF03b, TF03c, TF03d,

TF03e, TF03f, TF03g,

TF15a, TF33a, TF34a,

TF35a)

Joggins Formation,

Cumberland Group -

Joggins,

Archer et al., 1995

Lower Port Hood

Formation,

Cumberland Group -

This work (TF04a, TF05a,

TF10a, TF12a, TF12b,

TF13a, TF17a, TF17b,

TF17c, TF17d, TF17e,

TF18a, TF18b, TF18c,

TF19a)

Upper Port Hood

Formation,

Cumberland Group -

this work (TF1la, TF1lb,

TF11c, TF26a, TF26b,

TF27a, TF28a, TF29a,

TF30a, TF31a)
Circulichnus montanus

Cruziana problematica

Diplopodichnus biformis

Gordia marina

Helminthopsis hieroglyphica

Planolites terraenovae

Rusophycus carbonarius

cf. Rusophycus

Selenichnites isp.

Cf. Undichnus

Interface trails, type $A$

Interface trails, type B

Interface trails, type $C$

Small ovate pits, type A

(+ Trackways)

Cochlichnus anguineus

Gordia isp.

Haplotichnus? isp.

Plangtichnus erraticus

Taenidium barretti

Treptichnus pollardi

(+ Trackways)

Cruziana problematica

Didymaulichnus cf. lyelli

Helminthopsis abeli

Helminthopsis hieroglyphica

Palaeophycus striatus

cf. Palaeophycus

cf. Planolites

Rusophycus carbonarius

Thalassinoides suevicus

Small ovate pits, type B

(+ Trackways)

Conichnus isp.

Cochlichnus anguineus

Cochlichnus isp.

cf. Palaeophycus

Phycodes pedum

Planolites beverleyensis

Taenidium barretti

Undichnus binus

Undichnus consulcus

Coprolites

(+ Trackways)
Taenidium barretti

\section{Acknowledgements}

B. Broster, C. Laury, A. Park, and P. Stringer commented upon earlier drafts of this work. R. Metz and D. Mossman are thanked for their constructively critical reviews. A. Gómez and R. McCulloch provided technical assistance. This work was funded by an NSERC Canada grant to RKP.

Aceñolaza, F.G. and Buatois, L.A. 1991. Trazas fosiles del Paleozoico Superior continental Argentino. Ameghiniana, 28, pp. 89108.

-... 1993. Nonmarine perigondwanic trace fossils from the late Paleozoic of Argentina. Ichnos, 2, pp. 183-203.

AlleN, J.R.L. and Williams, B.P.J. 1981. Beaconites antarcticus: a giant channel-dwelling trace fossil from the Lower Old Red Sandstone of South Wales and the Welsh Borders. Geological Journal, 16, pp. 255-269.

AlPert, S.P. 1975. Planolites and Skolithos from the Upper Precambrian-Lower Cambrian White-Inyo Mountains, California. Journal of Paleontology, 49, pp. 508-521.

Amstutz, G.C. 1958. Coprolites: a review of the literature and a study of specimens from southern Washington. Journal of Sedimentary Petrology, 28, pp. 498-508.

Anderson, A.M. 1976. Fish trails from the Early Permian of South Africa. Palaeontology, 19, pp. 397-409.

Archer, A.W., Calder, J.H., Gibling, M.R., Naylor, R.D., Reid, D.R., and WightmaN, W.G. 1995. Invertebrate trace fossils and agglutinated foraminifera as indicators of marine influence within the classic Carboniferous section at Joggins, Nova Scotia, Canada. Canadian Journal of Earth Sciences, 32, pp. 2027-2039.

BELT, E.S. 1965. Stratigraphy and paleogeography of Mabou Group and related middle Carboniferous facies, Nova Scotia, Canada. Geological Society of America Bulletin, 76, pp. 776-802.

BERG, T.M. 1977. Bivalve burrow structures in the Bellvale sandstone, New Jersey and New York. New Jersey Academy of Science Bulletin, 22, pp. 1-5.

Billings, E. 1862. New species of fossils from different parts of the Lower, Middle, and Upper Silurian rocks of Canada. In Palaeozoic Fossils, Volume 1 (1861-1865). Geological Survey of Canada Advanced Sheets, pp. 96-168.

Bjerstedt, T.W. and Erickson, J.M. 1989. Trace fossils and bioturbation in peritidal facies of the Potsdam-Theresa formations (CambrianOrdovician), Northwest Adirondacks. Palaios, 4, pp. 203224.

Bradshaw, M.A. 1981. Palaeoenvironmental interpretations and systematics of Devonian trace fossils from the Taylor Group (Lower Beacon Supergroup), Antarctica. New Zealand Journal of Geology and Geophysics, 24, pp. 615-652.

BradY, L.F. 1947. Invertebrate tracks from the Coconino Sandstone of northern Arizona. Journal of Paleontology, 21, pp. 466-472.

Broadhurst, F.M., Simpson, I.M., and Hardy, P.G. 1980. Seasonal sedimentation in the Upper Carboniferous of England. Journal of Geology, 88, pp. 639-651.

Bromley, R.G. 1996. Trace Fossils: Biology and Taphonomy. Second Edition. Chapman and Hall, London, $340 \mathrm{p}$.

Brock, P.M. 1987. A note on the trace fossil Beaconites barretti in the Old Red Sandstone of Co. Dublin, Ireland. Proceedings of the Geologists' Association, 98, pp. 259-263.

Buatols, L.A. and Mangano, M.G. 1993. Trace fossils from a Carboniferous turbiditic lake: implications for the recognition of additional nonmarine ichnofacies. Ichnos, 2, pp. 237. 258. 
BuckMan, J.O. 1995. A comment on annulate forms of Palaeophycus Hall 1847: with particular reference to $P$. 'annulatus' sensu Pemberton and Frey 1982, and the erection of $P$. crenulatus ichnosp. nov. Ichnos, 4, pp. 131-140.

Carroll, R.L., Belt, E.S., Dineley, D.L., Baird, D., and McGregor, D.C. 1972. Vertebrate Paleontology of Eastern Canada. XXIV International Geological Congress, Montreal 1972, Field Excursion A59, 113 p.

Chamberlain, C.K. 1975. Recent lebensspuren in nonmarine aquatic environments. In The Study of Trace Fossils. Edited by R.W. Frey. Springer Verlag, New York, pp. 431-458.

Chisholm, J.I. 1985. Xiphosurid burrows from the Lower Coal Measures (Westphalian A) of West Yorkshire. Palaeontology, 28, pp. 619-628.

Clausen, C.K. and Vilhiálmsson, M. 1986. Substrate control of Lower Cambrian trace fossils from Bornholm, Denmark. Palaeogeography, Palaeoclimatology, Palaeoecology, 56, pp. 51-68.

Crimes, T.P. and Anderson, M.M. 1985. Trace fossils from Late Precambrian-Early Cambrian strata of S.E. Newfoundland: temporal and environmental implications. Journal of Paleontology, 59, pp. 310-343.

Crimes, T.P., Goldring, R., Homewood, P., Van Stuijvenberg, J., and WinkleR, W. 1981. Trace fossil assemblages of deepsea fan deposits, Gurnigel and Schlieren flysch (CretaceousEocene), Switzerland. Eclogae Geologicae Helvetiae, 74, pp. 953-995.

D'Allesandro, A. and Bromley, R.G. 1987. Meniscate trace fossils and the Muensteria-Taenidium problem. Palaeontology, 30, pp. 743-763.

Dam, G. and Anreassen, F. 1990. High-energy ephemeral stream deltas; an example from the Upper Silurian Holmestrand Formation of the Oslo Region, Norway. Sedimentary Geology, 66, pp. 197-225.

Dawson, J.W. 1868. Acadian Geology. Second Edition. MacMillan and Company, London, $694 \mathrm{p}$.

Demathieu, G., Gand, G., and Toutn-Morin, N. 1992. La palichnofaune des bassins Permiens Provençaux. Géobios, 25, pp. 19-54.

D'Orbigny, A. 1842. Voyage dans l'Amérique méridionale (le Brésil, la République oriental de l'Uruguay, la République Argentine, la Patagonie, la République du Chili, la République de Bolivia, la République du Péron) exécuté pendant les années $1826,1827,1829,1830,1831,1832$, et 1833 . v. 3, pt. 4 (Paléontologie). Levrault, Strasbourg, 188 p.

Durand, J. 1985. Les Grès Armoricain. Sédimentologie - Traces fossiles. Milieux de dépôt Centre Armoricain d'etude structurale des Socles Mémoires et documents, 3, $150 \mathrm{p}$.

Dzık, J. 1996. Paper review: Notostracan trackways and parataxonomy. Acta Palaeontologica Polonica, 41, p. 58.

Eagar, R.M.C., Baines, J.G., Collinson, J.D., Hardy, P.G., Okolo, S.A., and Pollard, J.E. 1985. Trace fossil assemblages and their occurrence in Silesian (mid-Carboniferous) deltaic sediments of the central Pennine Basin, England. In Biogenic Structures: Their Use in Interpreting Depositional Environments. Edited by H.A. Curran. Society of Economic Paleontologists and Mineralogists, Special Publication 35, pp. 99-149.

Ehrenberg, K. 1944. Ergănzende Bemerkungen zu den seinerzeit aus dem Miozăn von Burgschleinitz beschriebenen Gangkernen und Bauten dekapoder Krebse. Paläontologische Zeitschrift, 23, pp. 354-359.

Ekdale, A.A. and Bromley, R.G. 1984. Comparative ichnology of shelf-sea and deep-sea chalk. Journal of Paleontology, 58, pp. 322-332.

Ekdale, A.A., Pemberton, S.G., and Bromley, R.G. 1984. Ichnology: Trace Fossils in Sedimentology and Stratigraphy. Society of Economic Paleontologists and Mineralogists, Short Course $15,317 \mathrm{p}$.

Emmons, E. 1844. The Taconic System; based on observations in New York, Massachusetts, Maine, Vermont and Rhode Island. Caroll and Cook, Albany, 68 p.

Fillion, D. and Pickerill, R.K. 1984. Systematic ichnology of the Middle Ordovician Trenton Group, St. Lawrence Lowland, eastern Canada. Maritime Sediments and Atlantic Geology, 20 , pp. $1-41$.

Fillion, D. and Pickerill, R.K. 1990. Ichnology of the Upper Cambrian? to Lower Ordovician Bell Island and Wabana groups of eastern Newfoundland, Canada. Palaeontographica Canadiana, 7, 119 p.

FREY, R.W. and BROMLEY, R.G. 1985. Ichnology of American chalks: the Selma Group (Upper Cretaceous), western Alabama. Canadian Journal of Earth Sciences, 22, pp. 801-828.

FrEY, R.W. and Howard, J.D. 1985. Trace fossils from the Panther Member, Star Point Formation (Upper Cretaceous), Coal Creek Canyon, Utah. Journal of Paleontology, 59, pp. 370404.

---- 1990. Trace fossils and depositional sequences in a clastic shelf setting, Upper Cretaceous of Utah. Journal of Paleontology, 64, pp. 803-820.

FREY, R.W., HOWARD, J.D., and PRYOR, W.A. 1978. Ophiomorpha: its morphologic, taxonomic and environmental significance. Palaeogeography, Palaeoclimatology, Palaeoecology, 23, pp. 199-229.

Frey, R.W., Pemberton, S.G., and Fagerstrom, J.A. 1984. Morphological, ethological and environmental significance of the ichnogenera Scoyenia and Ancorichnus. Journal of Paleontology, 58, pp. 511-518.

FüRSICH, F.T. 1973. A revision of the trace fossils Spongeliomorpha, Ophiomorpha, and Thalassinoides. Neues Jahrbuch fur Mineralogie Geologie und Paläontologie Monatshefte, 1973, pp. 719-735.

---- 1974. Ichnogenus Rhizocorallium. Palăontologische Zeitschrift, 48 , pp. $16-28$.

Gersib, G.A. and McCABE, P.J. 1981. Continental coal-bearing sediments of the Port Hood Formation (Carboniferous), Cape Linzee, Nova Scotia, Canada. In Recent and Ancient Nonmarine Depositional Environments: Models for Exploration. Edited by F.G. Ethridge and R.M. Flores. Society of Economic Paleontologists and Mineralogists, Special Publication 31, pp. 95-108.

Gevers, J.W., Frakes, L.A., Edwards, L.N., and Marzolf, J.E. 1971. Trace fossils in the Lower Beacon Sediments (Devonian) Darwin Mountains, Southern Victoria Land, Antarctica. Journal of Paleontology, 45, pp. 81-94.

Geyer, G. and Uchman, A. 1995. Ichnofossil assemblages from the Nama Group (Neoproterozoic-Lower Cambrian) in Namibia and the Proterozoic-Cambrian boundary problem. In Morocco ' 95 , the lower-middle Cambrian standard of western Gondwana. Edited by G. Geyer and E. Landing. Beringeria Special Issue, 2, pp. 175-202.

Gibling, M.R. 1995. Upper Paleozoic rocks, Nova Scotia. In Chapter 5 of Geology of the Appalachian-Caledonian Orogen in Canada and Greenland. Edited by $\mathrm{H}$. Williams. Geological Survey of Canada, Geology of Canada, 6, pp. 493-523.

Gibson, G.G. 1989. Trace fossils from Late Precambrian Carolina Slate Belt, south-central North Carolina. Journal of Paleontology, 63, pp. 1-10.

GIERLOWSKI-KORDESCH, E. 1991. Ichnology of an ephemeral lacustrine/ alluvial plain system: Jurassic East Berlin Formation, Hartford Basin, USA. Ichnos, 1, pp. 221-232.

GoldRNa, R. and PollaRd, J.E. 1995. A re-evaluation of Ophiomorpha 
burrows in the Wealden Group (Lower Cretaceous) of southern England. Cretaceous Research, 16, pp. 665-680.

-..- 1996. Ichnotaxonomic revision and the importance of type material. Palaeontology Newsletter, 31, pp. 7-8.

Goldring, R., Pollard, J.E., and Taylor, A.M. 1997. Naming trace fossils. Geological Magazine, 134, 264-268.

Gordon, E.A. 1988. Body and trace fossils from the middle-upper Devonian Catskill Magnafacies, southeastern New York, U.S.A. In Devonian of the World., Volume II, Sedimentation. Edited by N.J. McMillan, A.F. Embry and D.J. Glass. Proceedings of the 2nd International Symposium on the Devonian System, Calgary, Canada. Canadian Society of Petroleum Geologists, pp. 139-155.

Graham, J.R. and Pollard, J.E. 1982. Occurrence of the trace fossil Beaconites antarcticus in the Lower Carboniferous fluviatile rocks of County Mayo, Ireland. Palaeogeography, Palaeoclimatology, Palaeoecology, 38, pp. 257-268.

Gradzinski, R. and Uchman, A. 1994. Trace fossils from interdune deposits - an example from the Lower Triassic aeolian Tumlin Sandstone, central Poland. Palaeogeography, Palaeoclimatology, Palaeoecology, 108, pp. 121-138.

GRAY, J. 1953. Undulatory propulsion. Quarterly Journal of Microscope Science, 94, pp. 551-578.

Guanzhong, W. 1993. Xiphosurid trace fossils from the Westbury Formation (Rhaetian) of southwest Britain. Palaeontology, 36, pp. 111-122.

Guerra-Sommer, M., Piccoli, A.E.M., and Dias-Fabricio, M.E. 1984. Icnofósseis em varvitos do Grupo Itararé, Permiano Inferior, Bacia Do Paraná, RS, Brasil. In Memoria III Congreso Latinoamericano de Paleontologia. México, pp. 130-139.

HAKEs, W.G. 1976. Upper Pennsylvanian megacyclothems, northeast Kansas. University of Kansas Paleontological Contributions Article, 63, $46 \mathrm{p}$.

Hall, J. 1847. Palaeontology of New York, Volume 1. Containing descriptions of the organic remains of the Lower Division of the New York System (equivalent of the Lower Silurian rocks of Europe). C. van Benthuysen, State of New York, Albany, New York, 338 p.

...-. 1852. Palaeontology of New York, Volume 2. Containing descriptions of the organic remains of the Lower Middle Division of the New York System (equivalent in part to the Middle Silurian rocks of Europe). C. van Benthuysen, State of New York, Albany, New York., 362 p.

Hallam, A. 1975. Preservation of trace fossils. In The Study of Trace Fossils. Edited by R.W. Frey. Springer Verlag, New York, pp. 55-63.

Hambin, A.P. 1989. Sedimentology, tectonic control, and resource potential of the Upper Devonian-Lower Carboniferous Horton Group, Cape Breton Island, Nova Scotia. Unpublished Ph.D. thesis, University of Ottawa, Ottawa, Canada, $300 \mathrm{p}$.

HaN, Y. and PICKerILL, R.K. 1994. Phycodes templus isp. nov. from the Lower Devonian of northwestern New Brunswick, eastern Canada. Atlantic Geology, 30, pp. 37-46.

---- 1995. Taxonomic revision of the ichnogenus Helminthopsis Heer 1877 with a statistical analysis of selected ichnospecies. Ichnos, 4, pp. 83-118.

Häntzschel, W. 1962. Trace fossils and problematica. In Treatise on Invertebrate Paleontology, Part W. Edited by R.C. Moore. Geological Society of America and University of Kansas Press, Lawrence, Kansas, pp. W178-W245.

-..-- 1975. Trace fossils and problematica. In Treatise on Invertebrate Paleontology, Part W. Miscellanea, Supplement 1. Series edited by C. Teichert. Geological Society of America and University of Kansas Press, Lawrence, Kansas, pp. W1W269.
Hantzschel, W., El-Baz, F., and Amstutz, G.C. 1968. Coprolites, an Annotated Bibliography. Geological Society of America, Memoir 108, 132 p.

HEeR, O. 1877. Flora fossilis Helvetiae. Die vorweltliche Flora der Schweiz. J.Würster and Company, 182 p.

Higgs, R. 1988. Fish trails in the Upper Carboniferous of SouthWest England. Palaeontology, 31, pp. 255-272.

Hitchсоск, E. 1858. Ichnology of New England. A report on the sandstone of the Connecticut Valley, especially its footprints. W. White, Boston, $220 \mathrm{p}$.

HowARD, J.D. and FREY, R.W. 1984. Characteristic trace fossils in nearshore to offshore sequences, Upper Cretaceous of eastcentral Utah. Canadian Journal of Earth Sciences, 21, pp. 200-219.

International Commission on Zoological Nomenclature (I.C.Z.N.). 1985. International Code of Zoological Nomenclature. (Third Edition Adopted by the 20th General Assembly of the International Union of Biological Sciences, 1985). International Trust for Zoological Nomenclature in association with the British Museum (Natural History), London, and University of California Press, Berkeley and Los Angeles, 338 p.

Johnson, E.W., Briggs, D.E.G., Suthren, R.J., Wright, J.L., and TUNNICLIF, S.P. 1994. Non-marine arthropod traces from the subaerial Ordovician Borrowdale Volcanic Group, English Lake District. Geological Magazine, 131, pp. 395-406.

KEIGHLEY, D.G. 1996. The stratigraphy, sedimentology, and ichnology of Mabou Group and Cumberland Group strata (middle Carboniferous) of western Cape Breton Island, Nova Scotia, eastern Canada. Unpublished Ph.D. thesis, University of New Brunswick, Fredericton, Canada, 705 p.

KeIGHLEY, D.G. and PICKERILL, R.K. 1994. The ichnogenus Beaconites, and its relationship to Ancorichnus and Taenidium. Palaeontology, 37, pp. 305-337.

-..- 1995. Commentary: the ichnotaxa Palaeophycus and Planolites, historical perspectives and recommendations. Ichnos, 3, pp. 301-309.

---- 1996a. The evolution of fluvial systems in the Port Hood Formation (Upper Carboniferous), western Cape Breton Island, eastern Canada. Sedimentary Geology, 106, pp. 97. 144.

---- 1996b. Ichnotaxonomic revision and the importance of type material - an alternative view. Palaeontology Newsletter, 32 , pp. 8-12.

-.-.- 1996c. Small compound Cruziana, Rusophycus, and related ichnotaxa: the nomenclatural debate and systematic ichnology, with examples from eastern Canada. Ichnos, 4, pp. 261-285.

KENNEDY, W.J. 1967. Burrows and surface traces from the Lower Chalk of southern England. British Museum (Natural History) Bulletin, Geology 15, pp. 125-167.

Kim, J-L, SEO, Y-S., and Park, S-I. 1992. Trace fossils from the Yeongheung Formation, Yeongweol, Korea. Journal of the Korean Earth Science Society, 13, pp. 313-326.

Kitchell, J.A. and ClaRK, D.L. 1979. A multivariate approach to biofacies analysis of deep-sea traces from the central Arctic. Journal of Paleontology, 53, pp. 1045-1067.

Ksiażkiewicz, M. 1977. Trace fossils in the flysch of the Polish Carpathians. Palaeontologia Polonica 36, 208 p.

Linck, O. 1942. Die spur Isopodichnus. Senckenbergiana, 25, pp. 232-255.

MaCNAUGhton, R.B. and PiCKERILL, R.K. 1995. Invertebrate ichnology of the nonmarine Lepreau Formation (Triassic), southern New Brunswick, eastern Canada. Journal of Paleontology, 69, pp. 160-171.

MalllaRd, G.A. 1887. Considérations sur les fossiles décrits comme 
Algues. Mémoires de la société paléontologique Suisse 14, pp. 1-40.

MajoR, D.M. 1939. Origin of Washington 'Coprolites'. Mineralogist, 7, pp. 363-388.

Martel, A.T. and Gibling, M.R. 1991. Wave-dominated lacustrine facies and tectonically controlled cyclicity in the Lower Carboniferous Horton Bluff Formation, Nova Scotia, Canada. In Lacustrine Facies Analysis. Edited by P. Anadon, L. Cabrera, and $\mathrm{K}$. Kelts. International Association of Sedimentologists Special Publication, 13, pp. 223-243.

Martinsson, A. 1970. Toponomy of trace fossils. In Trace Fossils. Edited by T.P. Crimes and J.C. Harper. Seel House Press, Liverpool, pp. 323-330.

McC ANn, T. and Pickerill, R.K. 1988. Flysch trace fossils from the Cretaceous Kodiak Formation of Alaska. Journal of Paleontology, 62, pp. 330-348.

METZ, R. 1987. Insect traces from nonmarine ephemeral puddles. Boreas, 16, pp. 189-195.

-..-- 1992. Trace fossils from the Lower Jurassic nonmarine Towaco Formation, New Jersey. Northeastern Geology, 14, pp. 29 34.

-.-- 1996. Newark Basin ichnology: the Late Triassic Perkasie Member of the Passaic Formation, Sanatoga, Pennsylvania. Northeastern Geology and Environmental Sciences, 18, pp. 118-129.

....- 1998 (in press). Nematode trails from the Late Triassic of Pennsylvania. Ichnos, 5.

MichelaU, P. 1956. Belorhaphe kochi (Ludwig 1869), eine Wurmspur im europäischen Karbon. Geologisches Jahrbuch, 71, pp. 299-329.

Mikulăš, R. 1991. Trace fossils from siliceous duricrusts in the Sárka and Dobrotivá Formations (Ordovician, central Bohemia). Casopis pro mineralogii a geologii, 36 , pp. 29-38.

....- 1992. Trace fossils from the Kosov Formation of the Bohemian Upper Ordovician. Sbornik geologických věd. Paleontologie, 32 , pp. 9-54.

.... 1993. New information on trace fossils of the Early Ordovician of Prague Basin (Barrandian area, Czech Republic). Journal of the Czech Geological Society, 38, pp. 171182.

Miller, M.F. and Collinson, J.W. 1994. Trace fossils from Permian and Triassic sandy braided stream deposits, central Transantarctic Mountains. Palaios, 9, pp. 605-610.

Miller, S.A. 1889. North American geology and palaeontology for the use of amateurs, students and scientists. Western Methodist Book Concern, Cincinnati, Ohio, 664 p.

Moussa, M.T. 1970. Nematode trails from the Green River Formation (Eocene) in the Uinta Basin, Utah. Journal of Paleontology, 44, pp. 304-307.

MYANNIL, R.M. 1966. O vertikalnykh norkakh zaryvaniya $v$ Ordovikskikh izvestiyakakh Pribaltiki. In Organizm i sreda v geologischeskom proshlom. (Editor not given.) Akademiya Nauk SSSR, Paleontologicheskiy Institut, pp. 200-207.

MYrow, P. 1995. Thalassinoides and the enigma of Early Paleozoic open-framework burrow systems. Palaios, 10, pp. 58 74.

Nicholson, H.A. 1873. Contributions to the study of the Errant Annelides of the Older Palaeozoic rocks. Abstract. Proceedings of the Royal Society of London, 21, pp. 288-290.

OrLowsKI, S. 1989. Trace fossils in the Lower Cambrian sequence in the Switętokrzyskie Mountains, central Poland. Acta Palaeontologica Polonica, 34, pp. 211-231.

Osgood, R.G. 1970. Trace fossils of the Cincinnati area. Palaeontographica Americana, 6, pp. 281-444.
PaCześna, J. 1985. Skamienialości śladowe górnego wendu i dolnego kambru poludiowej Lubelszczyzny. Kwartalnik Geologiczny, 29, pp. 255-270.

...-. 1986. Upper Vendian and Lower Cambrian ichnocoenoses of Lublin region. Biuletyn Instytutu Geologicznego, 355, pp. 31-47.

PEARSON, P.N. 1992. Walking traces of the giant myriapod Arthropleura from the Strathclyde Group (Lower Carboniferous) of Fife. Scottish Journal of Geology, 28, pp. 127-133.

Pemberton, S.G. and Frey, R.W. 1982. Trace fossil nomenclature and the Planolites-Palaeophycus dilemma. Journal of Paleontology, 56, pp. 843-881.

---- 1983. Biogenic structures in Upper Cretaceous outcrops and cores. Field trip guidebook 8 , the Mesozoic of middle North America. Canadian Society of Petroleum Geologists, Calgary, Alberta, $161 \mathrm{p}$.

Pemberton, S.G., Frey, R.W., and Bromley, R.G. 1988. The ichnotaxonomy of Conostichus and other plug-shaped ichnofossils. Canadian Journal of Earth Sciences, 25, pp. 866-892.

Pickerill, R.K. 1992. Carboniferous nonmarine invertebrate ichnocoenoses from southern New Brunswick, eastern Canada. Ichnos, 2, pp. 21-35.

...- 1994. Nomenclature and taxonomy of invertebrate trace fossils. In The Palaeobiology of Trace Fossils. Edited by S.K. Donovan. John Wiley and Sons, Chichester, pp. 3-42.

Pickerill, R.K. and Keighley, D.G. 1997. Notostracan trackways and parataxonomy-acommentary. Acta Palaeontologica Polonica, 42 , pp. 171-174.

Pickerill, R.K. and KePPIE, J.D. 1981. Observations on the ichnology of the Meguma Group (?Cambro-Ordovician) of Nova Scotia. Maritime Sediments and Atlantic Geology, 17, pp. 130-138.

Pickerill, R.K. and Peel, J.S. 1991. Gordia nodosa isp. nov. and other trace fossils from the Cass Fjord Formation (Cambrian) of North Greenland. Gronlands Geologiske Undersogelse Rapport, 150, pp. 15-28.

Pickerill, R.K., Hurst, J.M., and Surlyk, F. 1982. Notes on Lower Palaeozoic flysch trace fossils from Hall Land and Peary Land, North Greenland. Gronlands Geologiske Undersøgelse Rapport, 108, pp. 25-29.

Pickerill, R.K., Fyffe, L.R., and Forbes, W.H. 1988. Late Ordovician-Early Silurian trace fossils from the Matapedia Group, Tobique River, western New Brunswick, Canada. II. Additional discoveries with descriptions and comments. Maritime Sediments and Atlantic Geology, 24, pp. 139-148.

Pickerill, R.K., Norman, Y., and Han, Y. 1995. New occurrence of Phycodes templus Han and Pickerill, 1994 with a taxonomic reassessment of Yangziichnus yichangensis Yang, 1984. Atlantic Geology, 31, pp. 1-6.

Pickerill, R.K., HaN, Y., and Jiang, D. 1998 (in press). Taxonomic revision of the ichnogenus Helminthopsis Heer 1877 with a statistical analysis of selected ichnospecies - a reply. Ichnos, 5.

Pollard, J.E. 1981. A comparison between the Triassic trace fossils of Cheshire and south Germany. Palaeontology, 24, pp. 555-588.

_- 1985. Isopodichnus, related arthropod trace fossils and notostracans from Triassic fluvial sediments. Transactions of the Royal Society of Edinburgh, Earth Sciences, 76, pp. 273-285.

...- 1988. Trace fossils in coal-bearing sequences. Journal of the Geological Society [London], 145, pp. 339-350.

Pollard, J.E. and Lovell, J.P.B. 1976. Trace fossils of the PermoTriassic of Arran. Scottish Journal of Geology, 12, pp. 209225.

Pollard, J.E., Steel, R.J., and Undersrud, E. 1982. Facies se- 
quences and trace fossils in lacustrine/fan delta deposits, Hornelen Basin (M. Devonian), western Norway. Sedimentary Geology, 32, pp. 63-87.

PRYOR, W.A. 1967. Biogenic directional features on several recent pointbars. Sedimentary Geology, 1, pp. 235-245.

Richter, R. 1850. Aus der thüringischen Grauwacke. Deutsche Geologische Gesellschaft, Zeitschrift, 2, pp. 198-206.

RidGLEY, J.L. 1989. Trace fossils and mollusks from the upper member of the Wanakah Formation, Chama Basin, New Mexico: evidence for a lacustrine origin. United States Geological Survey Bulletin, 1808C, pp. 1-15.

RIETH, A. 1932. Neue Funde spongeliomorpher Fucoiden aus dem Jura Schwabens. Geologie, Paläontologie Abhandlungen, N.F., Jena, 19, pp. 257-294.

RINDSBERG, A.K. 1994. Ichnology of the Upper Mississippian Hartselle Sandstone of Alabama, with notes on other Carboniferous formations. Geological Survey of Alabama Bulletin, 158, $107 \mathrm{p}$.

ROLFE, W.D.I. 1980. Early invertebrate terrestrial faunas. In The Terrestrial Environment and the Origin of Land Vertebrates. Edited by A.L. Panchen. Systematics Association Special Volume, 15, pp. 117-157.

Romano, M. and Whyte, M.A. 1987. A limulid trace fossil from the Scarborough Formation (Jurassic) of Yorkshire; its occurrence, taxonomy and interpretation. Proceedings of the Yorkshire Geological Society, 46, pp. 85-95.

...- 1990. Selenichnites, a new name for the ichnogenus Selenichnus Romano and Whyte, 1987. Proceedings of the Yorkshire Geological Society, 48, p. 226.

Rouault, M. 1850. Note préliminaire sur une nouvellle formation découverte dans le terrain silurien inférieur de la Bretagne. Bulletin de la Société Géologique de France Série 2, 7, pp. 724-744.

SCHINDEWOLF, O.H. 1928. Studien aus dem Marburger Buntsandstein. III-VII. Senckenbergiana, 10, pp. 16-54.

Seilacher, A. 1953. Studien zur Palichnologie II. Die fossilen Ruhespuren (Cubichnia). Neues Jahrbuch fur Geologie und Palăontologie Abhandlungen, 98, pp. 87-124.

...-. 1955. Spuren und Fazies im Unterkambrium. In Beiträge zur Kenntnis des Kambriums in der Salt Range (Pakistan). Edited by O.H. Schindewolf and A. Seilacher. Abhandlungen der mathematisch-naturwissenschaftlichen Klasse, Akademie der Wissenschaften und der Literatur in Mainz, 10, pp. 373399.

-..-. 1963. Lebensspuren und Salinitătsfazies. Fortschritte in der Geologie von Rheinland und Westfalens, 10, pp. 81-94.

..-.- 1964. Biogenic sedimentary structures. In Approaches to Paleoecology. Edited by J. Imbrie and N. Newell. Wiley, New York, pp. 296-316.

...-- 1967. Bathymetry of trace fossils. Marine Geology, 5, pp. 413-428.

Shaw, A.B. 1971. The butterfingered handmaiden. Journal of Paleontology, 45, pp. 1-5.

SMITH, R.M.H. 1987. Morphology and depositional history of exhumed Permian point bars in the southwestern Karoo, South Africa. Journal of Sedimentary Petrology, 57, pp. 19-29.
Soja, C.M. 1991. Silurian trace fossils in carbonate turbidites from the Alexander arc of southeastern Alaska. Ichnos, 1, pp. 173-181.

Stanley, D.C.A. and Pickerill, R.K. 1998 (in press). Systematic ichnology of the late Ordovician Georgian Bay Formation of Southern Ontario, Canada. Royal Ontario Museum, Life Science Contributions 162, 55 p.

Stanley, K.O. and FAgerstrom, J.A. 1974. Miocene invertebrate trace fossils from a braided river environment, Western Nebraska, U.S.A. Palaeogeography, Palaeoclimatology, Palaeoecology, 15 , pp. 63-82.

TUREK, V. 1989. Fish and amphibian trace fossils from Westphalian sediments of Bohemia. Palaeontology, 32, pp. 623-643.

UlRICH, E.O. 1904. Fossils and age of the Yakutat Formation. Description of collections made chiefly near Kodiak, Alaska. Harriman Alaska Expedition, 4: Geology and Paleontology, pp. 125-146.

VialOV, O.S. 1962. Problematica of the Beacon Sandstone at Beacon Heights, West Antarctica. New Zealand Journal of Geology and Geophysics, 5, pp. 718-732.

-.-.- 1971. Redkie problematiki iz mesozoya Pamira i Kaukaza. Paleontologikheskiy Sbornik, 7, pp. 85-93.

Wallace, H.R. 1968. The dynamics of nematode movement. Annual Reviews of Phytopathology, 6, pp. 91-114.

Walter, M.R., Elphinstone, R., and Heys, G.R. 1989. Proterozoic and Early Cambrian trace fossils from the Amadeus and Georgina Basins, central Australia. Alcheringa, 13, pp. 209-256.

Webby, B.D. 1970. Late Precambrian trace fossils from New South Wales. Lethaia, 3, pp. 79-109.

WETZEL, A. and BromLEY, R.G. 1996. Re-evaluation of the ichnogenus Helminthopsis - a new look at the type material. Palaeontology, 39, pp. 1-20.

Wetzel, A., Kamelger, A., and Bromley, R.G. 1998 (in press). Taxonomic review of the ichnogenus Helminthopsis, with a statistical analysis of selected ichnospecies - a discussion. Ichnos, 5.

WheATCROFT, R. 1986. Maestrichtian trace fossils from selected localities in the Chattachoochee River valley. In Stratigraphy and Sedimentology of Continental, Nearshore, and Marine Cretaceous Sediments of the Eastern Gulf Coastal Plain. Edited by J. Reinhardt. SEPM/AAPG annual meeting 1986, Field Trip 3, pp. 57-70.

YANG, S. 1986. Turbidite flysch trace fossils from China and their palaeoecology and palaeoenvironments. In Chinese Palaeontological Society. 13th-14th annual meetings, selected papers. Anjing Science and Technology Publishing Company, pp. 143-161.

Young, F.G. 1972. Early Cambrian and older trace fossils from the southern Cordillera of Canada. Canadian Journal of Earth Sciences, 9, pp. 1-17.

Zawiskie, J.M., Collinson, J.W., and Hammer, W.R. 1982. Trace fossils of the Permian-Triassic Takrouna Formation, northern Victoria Land, Antarctica. In Antarctic Earth Science. Edited by R.I. Oliver, P.R. James, and J.B. Jago. Cambridge University Press, Cambridge, pp. 215-220. 